\title{
Pathotype and Avirulence Gene Diversity of Pyricularia grisea in Thailand as Determined by Rice Lines Near-Isogenic for Major Resistance Genes
}

\author{
Poonsak Mekwatanakarn, Ubon Rice Research Center, Ubon Ratchathani, Thailand; Wichai Kositratana, Kaset- \\ sart University, Kamphanseng Campus, Nakhornprathom, Thailand; M. Levy, Department of Biological Sciences, \\ Purdue University, West Lafayette, IN 47907; and R. S. Zeigler, International Rice Research Institute, Manila, \\ Philippines
}

\begin{abstract}
Mekwatanakarn, P., Kositratana, W., Levy, M., and Zeigler, R. S. 2000. Pathotype and avirulence gene diversity of Pyricularia grisea in Thailand as determined by rice lines near-isogenic for major resistance genes. Plant Dis. 84:60-70.

Five hundred twenty-seven isolates of Pyricularia grisea were collected from trap rice cultivars of indigenous and exotic origin across three seasons at five sites in Thailand. Single conidium isolates were inoculated onto 15 rice lines near-isogenic (NILs) for resistance genes, one recurrent parent, and two local cultivars. One hundred seventy-five pathotypes were identified, of which 160 were represented by fewer than eight isolates. Predicted pathotype number was estimated at greater than 450 for the study region. Significant differences in pathotype diversity were detected across sites, seasons, and among isolates collected from exotic versus indigenous hosts. Isolates and pathotypes with greater numbers of virulence genes (as inferred from compatibility with NILs) were less common than those with fewer virulence genes. Analysis of virulence distributions among isolates grouped according to their MGR586 DNA-fingerprint similarities (i.e., "lineages") also showed that, for the most commonly represented lineages, isolates with fewer virulence genes predominated. Lineages represented by one or a few isolates had greater numbers of virulence genes. Lower frequency of recovery of isolates with accumulated virulence genes is consistent with an associated fitness penalty. Resistance genes $\mathrm{Pi} 1, \mathrm{Pi}$ $z-5$, and $P i t a^{2}$ were broadly effective across this population, compatibility with $P i 1$ and $P i z-5$ was very rare, and no isolate combined compatibility with both genes. Well-represented (more than 20 isolates) MGR586 lineages showed specific incompatibilities with some NILs, but these were restricted to Pi 1 and $P i z-5$. No combination of resistance genes would confer resistance across all lineages.
\end{abstract}

Additional keywords: blast disease, gene-for-gene relationship, lineage exclusion, Magnaporthe grisea, rarefaction

Blast, caused by the ascomycete Magnaporthe grisea (anamorph Pyricularia grisea) (37), is among the most devastating diseases of rice (Oryza sativa) and occurs in almost all rice-growing regions of the world. As fungicides are costly control measures beyond the means of most rice farmers, deployment of resistant cultivars has been the preferred means of disease management. However, cultivars released as resistant often show high levels of susceptibility within a few years. Pathogen populations are known to be pathotypically diverse, and there are numerous reports that this diversity may be due to continuous generation of novel pathogenic varia-

Corresponding author: R. S. Zeigler

E-mail: rzeigler@plantpath.ksu.edu

Current address of R. S. Zeigler: Department of Plant Pathology, 4024 Throckmorton Plant Sciences Center, Kansas State University, Manhattan.

Accepted for publication 21 September 1999.

Publication no. D-1999-1105-01R

(C) 2000 The American Phytopathological Society tion. Thus, resistance breakdown has been attributed to poor prerelease challenge by a representative sample of the pathogen population in the region targeted for cultivar release or to the appearance of new pathotypes (52).

Successful breeding of cultivars durably resistant to $P$. grisea has been hampered by difficulties in unambiguously and adequately characterizing virulence in pathogen populations in target environments. Differentially resistant rice lines for determining pathotypes are commonly developed to suit local populations because "international" sets are largely unsuitable for tropical populations (4). Most such sets have widely different genetic backgrounds, and lines may carry several major and/or environmentally sensitive minor resistance genes causing intermediate and poorly repeatable reactions to pathogen challenge, even under well-controlled conditions (27). Consequently, there has been no means to establish the avirulence gene diversity within $P$. grisea populations in the tropics. Even with reliable pathotyping, there remains the challenge of sampling essentially infinitely large populations for assessing pathotypic variation in order to help orient resistance breeding programs. New tools recently have been introduced as means to improve pathogen population characterization: near-isogenic lines (NILs) for major blast resistance genes for accurately assessing pathotype, and avirulence gene diversity and DNA fingerprinting to simplify characterization of the population structure.

Two sets of NILs are now available in which single major resistance genes against $P$. grisea have been introduced via repeated backcrosses into the genetic background of the broadly and highly susceptible "indica" and "japonica" rice cultivars CO39 and Lijiangxintuanheigu (LTH), respectively $(25,27)$. Thus, within the limits of the major genes incorporated into the sets, unambiguous pathotypes may now be assigned to isolates based on their reactions to the NILs. Following a gene-forgene model of a single host resistance gene corresponding to one pathogen avirulence gene in the rice blast pathosystem (42), the functional avirulence gene composition of an isolate can be inferred based on its aggregated incompatibility with the NILs. Nonfunctional avirulence is thus defined by compatibility with a NIL, without knowing whether the avirulence gene is absent, unexpressed, or functional for other purposes. For clarity in this paper, we will use the term "virulences" in place of "nonfunctional avirulence genes." Despite ample evidence that the gene-for-gene model describes the rice- $M$. grisea interaction, it remains an assumption that compatibility differences between two isolates on one NIL correspond to a difference in one avirulence gene.

The $P$. grisea genome contains multiple copies of a number of transposable elements (41), with the most widely used of these, MGR586, occurring in 40 to 60 copies well-distributed throughout the genome (16). Several analyses using MGR586 have shown that isolates within populations could be grouped according to their MGR586 "fingerprint" similarities $(8,22,24)$. Given that $P$. grisea is believed to reproduce asexually over most of its geographical range, these fingerprint groups, or "lineages," have been inferred to reflect clonal derivation from a common ancestor. In a number of population analyses, few such lineages, relative to the num- 
ber of pathotypes or population size, have been found to comprise the population $(8,24,38)$.

Different lineages appeared to have different virulence characteristics (23). One analysis of virulence spectra of isolates within lineages testing this hypothesis showed that while there was a large degree of pathotypic diversity within a lineage, all isolates within a lineage shared one or more avirulence(s) when tested against rice lines with differential resistance (49). It has been proposed, then, that population analysis for resistance breeding purposes could be simplified by first characterizing the population by lineage and then pathotyping with NILs to establish the virulence spectra of the lineages. The assembly of virulence spectra of the lineages would yield a view of the virulence characteristics of the population and could suggest combinations of resistance genes effective against the entire population. The assumptions and caveats for this approach are discussed in more detail elsewhere $(49,51,52)$.

We selected Thailand as a site for assessing virulence diversity using NILs, and ultimately for evaluating the potential for a breeding program based on pathogen population analyses using MGR586 fingerprinting. Rice in Thailand is grown on over 8 million hectares, and blast disease is a serious problem, particularly in the northern and northeastern rainfed lowland environments. Traditional cultivars are grown on approximately $30 \%$ of the area, while most of the remaining area is planted to purified selections from within traditional cultivars or from selections derived from crosses between traditional cultivars. A breeding program is underway to develop improved cultivars for the region, and one of its primary objectives is to incorporate high levels of blast resistance. We undertook a series of studies to characterize the Thailand $P$. grisea populations, focusing on the North and Northeast, in order to help improve the efficiency and long-term success of this breeding program. The detailed description of the populations using MGR586 fingerprinting and other molecular markers is to be described elsewhere.

Using the CO39 and LTH NILs and MGR586 fingerprinting, we address three issues in this paper: First, we assess the pathotype composition of Thailand $P$. grisea populations. Second, assuming a gene-for-gene relationship between major resistance genes in the host and avirulence genes in the pathogen, we use the reactions with NILs to assess the frequency and distribution of inferred avirulence genes. Based on the reaction patterns of a large number of isolates in the populations, we ask if the avirulence loci are randomly associated. With these data, we begin to explore whether trends in virulence complexity suggest fitness penalties associated with loss of avirulence. Third, we examine what relationship, if any, there is between virulence spectrum and MGR586-defined lineage, and what implications this may have for resistance breeding in rice.

\section{MATERIALS AND METHODS}

Collection and maintenance of isolates. Isolates of $P$. grisea were collected from trap nurseries planted at five sites and farmer fields in Thailand (Fig. 1) from 1993 to 1994 . The trap nurseries consisted of lines and cultivars known to differ in resistance to the pathogen and a range of local cultivars (Table 1), and were managed using standard protocol (18). The cultivars were grouped based on their field reactions at five sites (Table 1). Sites were located in the principal rice growing regions of Thailand that are separated by mountain ranges. Ubon Rice Research Center (UBN) is the principal breeding center for the Northeast, and field plots of segregating and advanced lines are managed to maximize disease severity and pathotypic diversity (11). Khon Kaen Rice Experimental Station (KKN), Phrae Rice Research Center (PRE), Sanpatong Rice Experimental Station (SPT), and Ratchaburi Rice Experimental Station (RBR) are breeding and screening sites for evaluation of advanced breeding lines. Isolates were collected from discrete lesions from approximately 30-day-old plants. Singleconidium isolates were obtained by incubating infected leaves for $24 \mathrm{~h}$ in a humid chamber, then streaking sporulating lesions on $1 \%$ water agar and picking single germinating conidia. Colonies were grown on rice polish agar and stored on filter paper for repeated access to original isolates. Isolates were classified into MGR586 lineages following the process set forth by Levy et al. (23), as modified by Chen et al. (8), and the detail characterization of the $P$. grisea population by MGR586 lineages in Thailand was done by Mekwatanakarn (30).

Inoculum preparation and inoculation. Stock isolates were recultured from

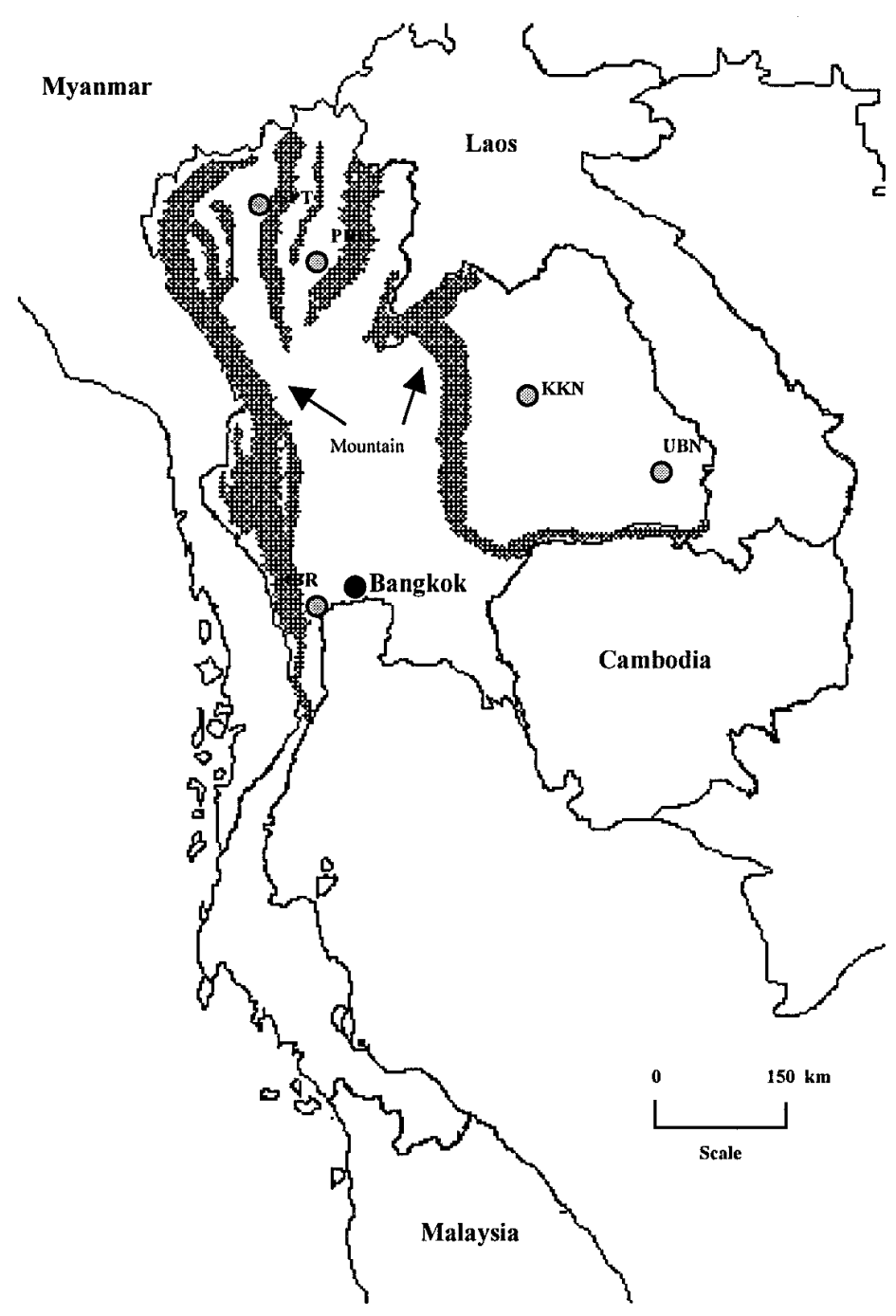

Fig. 1. Location of collection sites in Thailand. KKN $=$ Khon Kaen Rice Experimental Station; UBN $=$ Ubon Rice Research Center; PRE $=$ Phrae Rice Research Center; SPT = Sanpatong Rice Experimental Station; RBR = Ratchaburi Rice Experimental Station. KKN and UBN are in the northeastern region, $\mathrm{RBR}$ is in the central region, and SPT and PRE are in the northern region. 
storage on PDA agar plate with streptomycin at $10 \mathrm{mg}$ per $250 \mathrm{ml}$ of medium. Fiveday-old cultures of the fungus were transferred onto rice-polish agar plates

incubated at $25^{\circ} \mathrm{C}$ for 7 days. The plates were placed under continuous fluorescent light for 4 days at $25^{\circ} \mathrm{C}$ to induce sporulation. Conidia were scraped from incubated

Table 1. Rice line composition of trap nurseries, their origins, R-gene composition of NILs, and their field reactions of indigenous and exotic rice lines at the different sample sites in Thailand from 1993 to 1995

\begin{tabular}{|c|c|c|c|c|c|c|}
\hline \multirow[b]{2}{*}{ Line $^{w}$} & \multirow[b]{2}{*}{ Origin $^{x}$} & \multicolumn{5}{|c|}{ Reaction $^{y}$} \\
\hline & & $\mathbf{K K N}^{\mathbf{z}}$ & $\mathbf{U B N}^{\mathbf{z}}$ & $\mathbf{P R E}^{\mathbf{z}}$ & SPT $^{\mathbf{z}}$ & $\mathbf{R B R}^{\mathbf{z}}$ \\
\hline Group I & E, L & $\mathrm{S}$ & $\mathrm{S}$ & $\mathrm{S}$ & $\mathrm{S}$ & $\mathrm{S}$ \\
\hline Group II & E, L & $\mathrm{R}$ & $\mathrm{R}$ & $\mathrm{R}$ & $\mathrm{R}$ & $\mathrm{R}$ \\
\hline Group III & E, L & $\mathrm{S}$ & $\mathrm{R}$ & $\mathrm{R}$ & $\mathrm{R}$ & $\mathrm{R}$ \\
\hline Group IV & E, L & $\mathrm{R}$ & $\mathrm{R}$ & $\mathrm{R}$ & $\mathrm{R}$ & $\mathrm{S}$ \\
\hline Group V & E, L & $\mathrm{R}$ & $\mathrm{R}$ & I & $\mathrm{R}$ & $\mathrm{R}$ \\
\hline Group VI & $\mathrm{E}$ & $\mathrm{R}$ & $\mathrm{R}$ & $\mathrm{R}$ & $\mathrm{S}$ & $\mathrm{R}$ \\
\hline Group VII & E, L, NIL & $\mathrm{S}$ & $\mathrm{s}$ & $\mathrm{S}$ & $\mathrm{R}$ & $\mathrm{S}$ \\
\hline Group VIII & E, L & S & $\mathrm{S}$ & $\mathrm{S}$ & I & $\mathrm{S}$ \\
\hline Group IX & $\mathrm{E}$ & $\mathrm{R}$ & $\mathrm{R}$ & _- & $\mathrm{R}$ & _- \\
\hline Group X & E, NIL & $\mathrm{S}$ & $\mathrm{S}$ & - & $\mathrm{R}$ & - \\
\hline Group XI & $\mathrm{E}$ & I & $\mathrm{R}$ & $\mathrm{R}$ & $\mathrm{R}$ & _- \\
\hline Group XII & E & $\mathrm{R}$ & $\mathrm{S}$ & $\mathrm{R}$ & $\mathrm{R}$ & - \\
\hline Group XIII & E & $\mathrm{S}$ & $\mathrm{S}$ & I & $\mathrm{S}$ & $\mathrm{S}$ \\
\hline Group XIV & $\mathrm{E}$ & $\mathrm{S}$ & $\mathrm{S}$ & $\mathrm{R}$ & $\mathrm{S}$ & _- \\
\hline Chaodang & $\mathrm{L}$ & I & $\mathrm{S}$ & $\mathrm{R}$ & $\mathrm{R}$ & $\mathrm{S}$ \\
\hline CNA4130 & $\mathrm{E}$ & I & $\mathrm{R}$ & I & $\mathrm{R}$ & $\mathrm{S}$ \\
\hline C101A51 & NIL & I & $\mathrm{R}$ & I & $\mathrm{R}$ & - \\
\hline Iguape Cateto & $\mathrm{E}$ & I & $\mathrm{R}$ & $\mathrm{S}$ & $\mathrm{R}$ & - \\
\hline Usen & $\mathrm{E}$ & I & $\mathrm{S}$ & I & $\mathrm{R}$ & _- \\
\hline Wundeaw & $\mathrm{L}$ & $\mathrm{R}$ & I & $\mathrm{R}$ & $\mathrm{R}$ & - \\
\hline Learmdern & $\mathrm{L}$ & $\mathrm{R}$ & $\mathrm{S}$ & $\mathrm{s}$ & - & $\mathrm{R}$ \\
\hline Kato & E & $\mathrm{R}$ & $\mathrm{R}$ & $\mathrm{S}$ & $\mathrm{R}$ & - \\
\hline Tsuyuake & E & $\mathrm{R}$ & $\mathrm{S}$ & - & $\mathrm{R}$ & - \\
\hline GP15 & $\mathrm{L}$ & $\mathrm{S}$ & I & I & I & $\mathrm{R}$ \\
\hline RD25 & $\mathrm{L}$ & $\mathrm{S}$ & I & $\mathrm{R}$ & - & - \\
\hline СРА60 & $\mathrm{L}$ & $\mathrm{S}$ & $\mathrm{S}$ & I & $\mathrm{R}$ & I \\
\hline LY148 & $\mathrm{L}$ & $\mathrm{S}$ & $\mathrm{S}$ & I & $\mathrm{S}$ & I \\
\hline Praratthan & $\mathrm{L}$ & $\mathrm{S}$ & $\mathrm{S}$ & I & I & $\mathrm{s}$ \\
\hline Phraesawan & $\mathrm{L}$ & $\mathrm{S}$ & $\mathrm{S}$ & I & I & - \\
\hline RD10 & $\mathrm{L}$ & $\mathrm{S}$ & $\mathrm{S}$ & I & I & I \\
\hline RD21 & $\mathrm{L}$ & $\mathrm{S}$ & $\mathrm{S}$ & I & I & $\mathrm{R}$ \\
\hline RD7 & $\mathrm{L}$ & $\mathrm{S}$ & $\mathrm{S}$ & $\mathrm{R}$ & $\mathrm{R}$ & $\mathrm{S}$ \\
\hline Widni & $\mathrm{L}$ & $\mathrm{S}$ & $\mathrm{S}$ & $\mathrm{S}$ & $\mathrm{R}$ & I \\
\hline RD3 & $\mathrm{L}$ & $\mathrm{S}$ & $\mathrm{S}$ & $\mathrm{S}$ & $\mathrm{R}$ & $\mathrm{R}$ \\
\hline Doiwon & $\mathrm{L}$ & $\mathrm{S}$ & $\mathrm{S}$ & $\mathrm{S}$ & $\mathrm{S}$ & $\mathrm{S}$ \\
\hline Yamatenishiki & E & $\mathrm{S}$ & I & - & $\mathrm{R}$ & - \\
\hline C101LAC & NIL & $\mathrm{S}$ & I & $\mathrm{R}$ & I & - \\
\hline Danau lLaut Tawar & $\mathrm{E}$ & $\mathrm{S}$ & I & $\mathrm{S}$ & $\mathrm{R}$ & $\mathrm{S}$ \\
\hline Arias & E & $\mathrm{S}$ & $\mathrm{R}$ & I & I & - \\
\hline IR22 & $\mathrm{E}$ & $\mathrm{S}$ & $\mathrm{R}$ & S & $\mathrm{R}$ & I \\
\hline K3 & $\mathrm{E}$ & $\mathrm{S}$ & $\mathrm{R}$ & $\mathrm{S}$ & $\mathrm{R}$ & - \\
\hline PI No. 4 & E & S & $\mathrm{S}$ & - & S & - \\
\hline Raminad Str. 3 & E & $\mathrm{S}$ & $\mathrm{S}$ & - & I & - \\
\hline Caloro & E & $\mathrm{S}$ & $\mathrm{S}$ & I & $\mathrm{R}$ & - \\
\hline Shenshou Ibaraki & E & $\mathrm{S}$ & $\mathrm{S}$ & $\mathrm{R}$ & $\mathrm{R}$ & - \\
\hline Shin 2 & E & $\mathrm{S}$ & $\mathrm{S}$ & $\mathrm{R}$ & I & - \\
\hline UPLRi-5 & $\mathrm{E}$ & $\mathrm{S}$ & $\mathrm{S}$ & $\mathrm{R}$ & $\mathrm{R}$ & $\mathrm{R}$ \\
\hline Zenith & E & $\mathrm{S}$ & $\mathrm{S}$ & $\mathrm{R}$ & $\mathrm{R}$ & - \\
\hline C101PKT & NIL & $\mathrm{S}$ & $\mathrm{S}$ & $\mathrm{S}$ & $\mathrm{S}$ & I \\
\hline Kinandang Patong & $\mathrm{E}$ & $\mathrm{S}$ & $\mathrm{S}$ & $\mathrm{S}$ & $\mathrm{R}$ & I \\
\hline
\end{tabular}

${ }^{\text {w} G r o u p ~ I ~=~ L: ~ K D M L 105, ~ K P M 148, ~ N S G 19, ~ N S P T, ~ N U B N 1, ~ R D 2, ~ R D 6, ~ R D 8, ~ R D 15 ; ~ E: ~ C O 39, ~}$ IR8, Achi Asahi. Group II = L: SPR60; E: Akiiyutaka, Cica 9, Colombia 1, CT69947-1-1-1-7-M, Dular, HD14, IR36, IR42, IR50, NP125, Oryzica Lianos4, Oryzica Lianos5, Tetep. Group III = L: SPR90; E: BR21, Fukuhikari, IAC47, Moroberekan, Samgangbyeo, Shimokita, Toride1. Group IV = L: MN62M, E: IAC165. Group V = L: HY71; E: CT6196-33-10-4-15-M, IRAT13. Group VI = E: IR72, IRAT216. Group VII = L: Dokmai, Munpoo, RD23; E: BL1, OS6 NIL: C101PKT, C105TTP4-23. Group VIII = L: GP41, KTH17; E: K59. Group IX = E: Ceysvoni, Fukunishiki, Kogahikari, Seominbyeo. Group X = E: KU115; NIL: C101TTP, C103TTP, C104LAC. Group XI = CT7244-92-1-52-1, IR47686-18-7B. Group XII = E: Carreon, K2. Group XIII = Azucena, Fujisaka5. Group XIV = Miyazaki7, Sha Tiao Tsao, Shinsetsu, Yamadabaki.

${ }^{\mathrm{x}} \mathrm{E}=$ exotic; $\mathrm{L}=$ local; $\mathrm{NIL}=$ near-isogenic line.

${ }^{\mathrm{y}} \mathrm{R}=$ score 0 to $4 ; \mathrm{S}=$ score 6 to 9 ; $\mathrm{I}=$ score 5 ; “-” = ungerminated seeds; scoring system based on IRRI (1988), observed in at least one season in 1993 or 1994.

${ }^{2} \mathrm{KKN}=$ Khon Kaen Rice Experimental Station, UBN = Ubon Rice Research Center, PRE $=$ Phrae Rice Research Center, SPT = Sanpatong Rice Experimental Station, RBR = Ratchaburi Rice Experimental Station. plates into 10 to $20 \mathrm{ml}$ of sterilized distilled water. Spore suspensions were filtered through nylon mesh, and spore concentration was adjusted to $5 \times 10^{4}$ conidia per $\mathrm{ml}$. Tween 20 was added to $0.02 \%$ just before inoculation.

A total of 527 isolates from 49 lineages was used to determine virulence spectrum of the population by inoculating two sets of NILs carrying different major resistance genes against $P$. grisea under controlled conditions. Ten NILs with the indica cultivar CO39 genetic background carried different resistant genes: C101LAC ( $P i$ l), C104LAC $\left(P i \quad l(t)^{L A C}\right)$, C103TTP $(P i$ $\left.1(t)^{T T P}\right)$, C101A51 (Pi z-5), C104PKT (Pi 3), C101PKT (Pi $\left.4^{a}(t)\right)$, C102PKT $(\mathrm{Pi}$ $\left.4^{a}(t)^{P K T}\right)$, C101TTP $\left(P i 4^{a}(t)^{T T P}\right)$, C105TTP4-L23 $\left(P i 4^{b}(t)\right)$, and CO39 (Pi a) $(19,27)$. Six NILs with japonica LTH genetic background were F98-7 $\left(\mathrm{Pi} \mathrm{K}^{m}\right)$, F124-1 (Pi ta), F128-1 (Pi $\left.t a^{2}\right)$, F145-2 (Pi b), F129-1 (Pi $k^{p}$ ), and F80-1 (Pi k) (25). Resistant (Hy71) and susceptible (KDML105) Thai cultivars and $\mathrm{CO} 39$ were included as checks. Ten seeds per rice line (two sets of NILs plus controls) were sown in rows in potting soil in plastic trays $(30 \times$ $45 \times 13 \mathrm{~cm}$ ), fertilized with $6 \mathrm{~g}$ of $16-16-8$ NPK per $10 \mathrm{~kg}$ of soil, with $4 \mathrm{~g}$ of ammonium sulfate added 12 to 14 days after seedling emergence. Trays with 21 - to 25 day-old seedlings (four-leaf stage) were placed on a rotating plate, and the seedlings were sprayed uniformly with spore suspension $\left(40 \mathrm{ml}, 5 \times 10^{5}\right.$ conidia $\mathrm{ml}^{-1}$ ) using a Badger-150 airbrush at 10 psi. Disease reactions of the inoculated plants were scored 7 days after inoculation using a 0 to 5 scale, where 0 to 3 was considered incompatible and 4 to 5 was considered compatible (27). Inoculation for each isolate was performed at least twice. In almost all cases, compatibility or incompatibility was clear. In those cases where the reactions were not clear, inoculations were repeated.

Virulence frequencies were calculated by summing the number of compatible reactions to the NILs and to CO39. Although some NILs used in these experiments have been described as carrying the same resistance gene (i.e., C101LAC, C104LAC, and C103TTP carry Pi $1(t)$, and C101PKT, C102PKT, and C101TTP carry Pi $4^{a}(t)$ ), differential reactions with some isolates suggested that they carried at least one additional gene or an allelic form of the reported gene. Alternatively, because of limitations of the isolates used to develop the NILs, the genes in some cases may have been incorrectly inferred to be identical. Therefore, reactions to all of the NILs were included in the analyses.

Data analyses. Pathotypic diversity was calculated by using the Shannon diversity index (14), $D=-\sum p_{i} \ln p_{i}$, where $p_{i}$ is the frequency of the $i$ th genotype. The estimated diversity, $D$, was normalized to correct for differences in sample size: $D^{\prime}=$ 
$D / \ln N$, where $N$ is the sample size $(12,26,40)$. To evaluate the pathotype distance between two subpopulations in a region and season, the Rogers index of proportional overlap $(2,15)$ was calculated as

$$
H_{R}=\frac{1}{2} \sum_{j}\left|p_{j 1}-p_{j 2}\right|
$$

where $p_{j 1}$ and $p_{j 2}$ are the frequencies in subpopulations 1 and 2 of pathotype group $j$, respectively. $H_{R}$ is zero when the same types are present in equal frequency in both samples. The maximum value of $H_{R}$ (1.0) is reached when all types in two samples are different.

Shannon's index conveniently combines abundance and evenness parameters but does not allow statistical comparison of the richness of populations with different sample sizes. "Rarefaction" was developed as a means of statistically describing species richness in a community. As applied in this case, pathotype richness can be described in a population in such a way as to permit comparisons among different populations $(13,20)$. Using this technique, the expected number of pathotypes, $E\left(S_{n}\right)$, in a random subsample from a population with an observed pathotype abundance distribution can be calculated as follows:

$$
E\left(S_{n}\right)=\sum_{i=1}^{s}\left[1-\frac{\left(\begin{array}{c}
N-m_{i} \\
n
\end{array}\right)}{\left(\begin{array}{c}
N \\
n
\end{array}\right)}\right]
$$

where $N$ is the total number of individuals collected, $S$ is the total number of patho- types in the collection, $m_{i}$ is the number of individuals of pathotype $i$ in the collection, and $n$ is the size of the subsample. The term for summation is the probability that a pathotype will be included in a sample. The expected number of pathotypes in a given sample size, therefore, is the sum of the probabilities that each pathotype will be included in the sample.

A "rarefaction curve" for each population to be compared is constructed with an endpoint at the observed number of pathotypes; then the expected number of pathotypes at smaller sample sizes is plotted, along with error bars calculated from the variance (43). $E(S)$ can be compared among populations at a standard sample size (usually the smallest among the collections being examined) for statistically significant differences. $E(S)$ distributions and variances for the different locations and years were calculated using a published FORTRAN algorithm $(35,43)$ modified by K. G. Schoenley (personal communication).

The predicted number of pathotypes in a population can be estimated, based on the number of rare pathotypes in a sample, as $S$ $=S_{o b s}+\left(a^{2} / 2 b\right)$, where $S_{o b s}$ is the actual number of pathotypes observed in the population, $a$ is the number of pathotypes represented by only one individual (isolate), and $b$ is the number of pathotypes represented by exactly two individuals (9).

Avirulences and virulences were inferred from incompatible and compatible reactions, respectively, with a given NIL. The mean number of virulences per isolate was calculated as $C_{i}=\sum_{j}\left(p_{j} v_{j}\right)$, and the mean virulences per pathotype was calculated as $C_{p}=1 / n \sum_{j} v_{j}, j=1 \ldots \ldots n$, where $p_{j}$ and $v_{j}$ are frequency and number of virulence alleles, respectively, of the $j$ th pathotype in the sample, and $n$ is the number of different pathotypes in the sample $(2,3)$. A generalized linear model in STATGRAPHICS Plus Version 3.0 was used to statistically compare the mean number of virulence alleles per pathotype and per isolate. The distinction between "rare" and "common" pathotypes and lineages was arbitrarily defined as the square root of the number of isolates in the most common pathotype or lineage, or between 7 and 8 , with $\geq 8$ considered common and $\leq 7$ rare.

To determine if there were negative associations of virulence in the populations, we first examined the populations for gametic phase equilibrium. Then we examined pairwise associations of virulence to identify which, if any, deviated from their expected frequencies (14). For gametic phase equilibrium analysis of avirulence loci, virulent and avirulent interactions for one NIL were inferred to correspond to alternate avirulence allelic states for the locus corresponding to the resistance gene. Each pathotype was treated as a unit in gametic phase equilibrium analysis; i.e., was represented by a single isolate. This correction for clonality is more conservative with respect to rejecting the null hypothesis of panmixia (29).

Overall associations among avirulence loci were evaluated following the multilocus variance test $(5,29)$, using specific compatibility data for each isolate. We

\begin{tabular}{|c|c|c|c|c|c|c|c|c|c|c|c|c|c|c|c|c|c|c|c|c|c|}
\hline \multirow{2}{*}{$\begin{array}{l}\text { Common } \\
\text { pathotype }\end{array}$} & \multirow[b]{2}{*}{$\mathrm{Ni}^{\mathrm{w}}$} & \multicolumn{2}{|c|}{$\mathrm{Nh}^{\mathrm{w}}$} & \multirow[b]{2}{*}{$\mathbf{N I}^{\mathbf{w}}$} & \multicolumn{16}{|c|}{ Differential NILs $^{\mathrm{x}}$} & \multirow[b]{2}{*}{ Navr $^{-w}$} \\
\hline & & $\mathbf{a}$ & $\mathbf{b}$ & & 1 & 2 & 3 & 4 & 5 & 6 & 7 & 8 & 9 & 10 & 11 & 12 & 13 & 14 & 15 & 16 & \\
\hline A & 65 & 21 & 19 & 15 & - & - & - & - & - & - & - & - & - & + & + & + & - & + & + & + & 6 \\
\hline B & 40 & 12 & 17 & 14 & - & - & - & - & - & - & - & - & - & + & + & + & - & - & + & + & 5 \\
\hline C & 24 & 6 & 10 & 15 & - & - & - & - & + & + & + & + & + & + & + & + & - & + & + & + & 11 \\
\hline D & 19 & 8 & 7 & 7 & - & - & - & - & + & + & + & + & - & + & - & - & - & - & - & + & 6 \\
\hline E & 18 & 5 & 7 & 13 & - & - & - & - & + & - & + & - & - & + & + & + & - & + & + & + & 8 \\
\hline F & 15 & 9 & 5 & 9 & - & - & - & - & + & + & + & + & - & + & + & + & - & + & + & + & 10 \\
\hline G & 15 & 4 & 9 & 8 & - & - & - & - & - & - & - & - & - & + & + & + & - & - & - & + & 4 \\
\hline $\mathrm{H}$ & 14 & 5 & 5 & 8 & - & - & - & - & - & - & - & - & - & + & - & - & - & - & - & + & 2 \\
\hline I & 12 & 5 & 7 & 10 & - & - & + & - & + & + & + & + & + & + & + & + & - & + & + & + & 12 \\
\hline $\mathrm{J}$ & 11 & 3 & 6 & 10 & - & - & - & - & - & - & + & - & - & + & + & + & - & + & + & + & 7 \\
\hline K & 10 & 5 & 4 & 8 & - & - & - & - & + & + & + & + & + & + & + & + & - & - & + & + & 10 \\
\hline L & 10 & 2 & 5 & 6 & + & - & + & - & + & + & + & + & + & + & + & + & - & + & + & + & 13 \\
\hline M & 10 & 3 & 7 & 8 & - & - & - & - & + & - & - & - & - & + & + & + & - & + & + & + & 7 \\
\hline $\mathrm{N}$ & 9 & 6 & 2 & 4 & - & - & - & - & + & + & + & + & - & + & + & + & - & - & + & + & 9 \\
\hline $\mathrm{O}$ & 8 & 2 & 6 & 4 & - & - & - & - & - & - & - & - & - & + & + & - & - & - & - & + & 3 \\
\hline $\begin{array}{l}\Sigma \text { Common } \\
\text { pathotype }\end{array}$ & 280 & & & & & & & & & & & & & & & & & & & & \\
\hline $\begin{array}{l}\Sigma \text { Rare } \\
\text { pathotype }^{y}\end{array}$ & 247 & $\ldots$ & $\ldots$ & $\ldots$ & $23^{z}$ & 22 & 38 & 10 & 167 & 90 & 167 & 135 & 92 & 238 & 180 & 183 & 44 & 114 & 147 & 235 & \\
\hline
\end{tabular}

Table 2. Pathotype of Pyricularia grisea isolates collected from five sites in Thailand in 1993 to 1994

${ }^{\mathrm{w}} \mathrm{Ni}=$ number of isolates per pathotype, $\mathrm{Nh}=$ number of host of origin $(\mathrm{a}=$ exotic host, $\mathrm{b}=$ indigenous host $)$ from which pathotype recovered, $\mathrm{Nl}=$ number of lineages from which pathotypes recovered, Navr $=$ number of inferred virulence genes per pathotype.

${ }^{\mathrm{x}} 1$ = C101LAC $\left(P i\right.$ 1), $2=\mathrm{C} 104 \mathrm{LAC}\left(P i 1(t)^{L A C}\right), 3=\mathrm{C} 103 \mathrm{TTP}\left(P i 1(t)^{T T P}\right), 4=\mathrm{C} 101 \mathrm{~A} 51(P i z-5), 5=\mathrm{C} 104 \mathrm{PKT}(P i 3), 6=\mathrm{C} 101 \mathrm{PKT}\left(P i 4^{a}(t)\right), 7=$ C102PKT $\left(P i 4^{a}(t)^{P K T}\right), 8=$ C101TTP $\left(P i 4^{a}(t)^{T T P}\right), 9=$ C105TTP-4-L23 $\left(P i 4^{b}(t)\right), 10=$ CO39 $(P i a), 11=$ F98-7 $\left(P i K^{m}\right), 12=$ F124-1 $(P i t a), 13=$

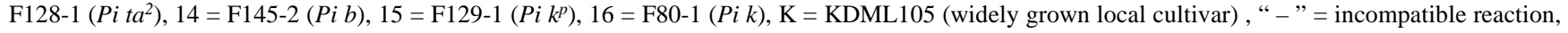
$"+"=$ compatible reaction.

y Among a total of 160 additional pathotypes, 117 were represented by only one isolate, 23 by 2 isolates, 8 by 3 isolates, 6 by 4 isolates, 2 by 7 isolates, 2 by 6 isolates, and 2 by 5 isolates.

${ }^{\mathrm{z}}$ Number of isolates within rare pathotypes with which this NIL was compatible. 
determined the variance in the number of pairwise allelic mismatches over all loci relative to that under the hypothesis of panmixia (i.e., random association of alleles). The index of association $\left(I_{A}\right)$ was used as a measure of the degree of association between loci. $I_{A}$ has an expected value of zero if there is no association between loci. The error variance of $I_{A}$, assuming no association, was used to calculate the upper $95 \%$ confidence limit, and $L$ was used to distinguish between values of $I_{A}$ that significantly differ from zero and those that do not.

Associations of virulence were assessed based on expected pair-wise frequencies calculated from the product of the observed frequency of each virulence. Deviations from expected frequencies were determined using a $\chi^{2}$ test with one degree of freedom.

\section{RESULTS}

Pathotype diversity. The exotic, indigenous, and CO39 NIL components of the trap nursery showed field susceptibility in one or more of the five trap nursery sites in the northern, northeastern, and central rice growing areas in 1993 to 1994 (Table 1). Khon Kaen and Ubon had the highest apparent pathogen diversity, with approximately 64 and $53 \%$, respectively, of lines showing susceptibility in at least one season. At the other sites, by contrast, fewer than $30 \%$ of the lines were susceptible. The lines showing differential susceptibility in Kohn Kaen (Group III) are japonica lines, while those lines showing the broadest resistance (group II) are improved indica lines. Of the 12 lines showing susceptibility at all sites, nine were indigenous cultivars, with one (KDML105) being the most widely grown cultivar in Thailand. Of the 14 lines showing uniform resistance, only one was indigenous; yet several are grown widely throughout Asia.

One hundred seventy-five pathotypes were detected from among 527 isolates inoculated on the two NIL sets (Table 2). Twenty-one pathotypes comprised $53 \%$ of the population, and these were detected in most of the sites. The remaining 160 pathotypes were rare $(<8$ isolates per pathotype): 117 pathotypes were represented by only one isolate, 23 by 2 isolates, 8 by 3 isolates, 6 by 4 isolates, 2 by 7 isolates, 2 by 6 isolates, and 2 by 5 isolates. From the numbers of "singleton" and "doubleton" pathotypes, the estimate of total number of pathotypes in the region is
473. With the exception of I and L, most of the common pathotypes were incompatible with Pi $1, P i z-5$, and $P i t a^{2}$.

Rarefaction curves indicate that when adjusted for sample size, the number of pathotypes in 1993WS was greater than that detected in either 1994 season (Fig. 2A). The common pathotypes were recovered from many cultivars (Table 2); but there were significantly more pathotypes detected from exotic lines than from indigenous cultivars (Fig. 2C). Common pathotypes were also found in the backgrounds of a range of MGR586-defined lineages (Table 2). Although the rarefaction curves for lineages with $\geq 28$ isolates showed that most had about the same number of pathotypes, lineage 14 had more pathotypes than the others (Fig. 2D).

Normalized Shannon indices of pathotype diversity were high at all sites (Table 3 ), and rarefaction curves showed no significant differences among pathotype richness at the different sites standardized for the sample size collected at Ratchaburi (Fig. 2B). But at larger sample sizes, significantly fewer pathotypes were detected at Khon Kaen than estimated for Ubon. Eleven of the 15 common pathotypes were found in all three geographical regions,
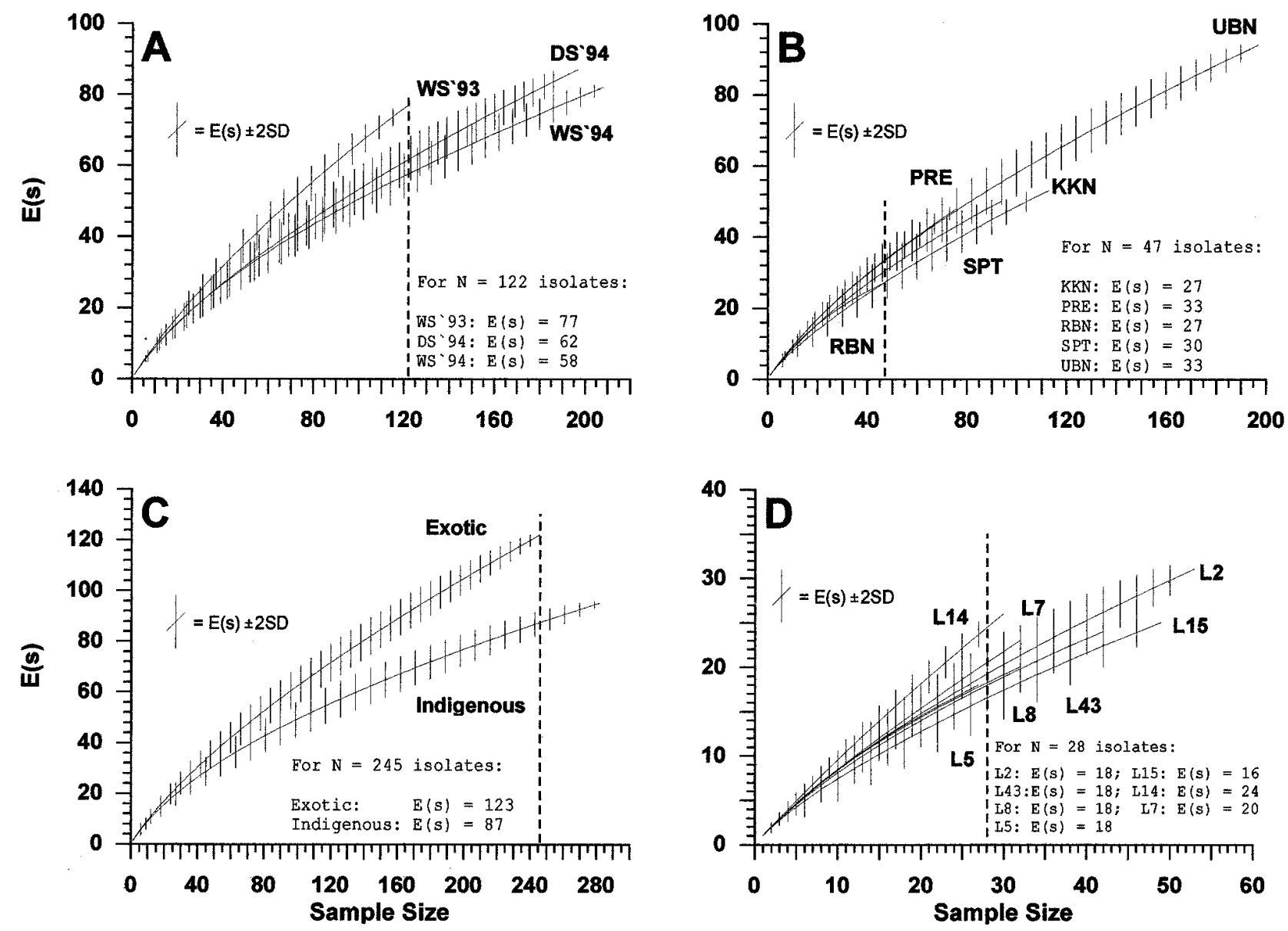

Fig. 2. Rarefaction curves for pathotype abundance by (A) season, (B) site (names as in Figure 1), (C) host of origin, and (D) selected pathogen MGR586 lineages. $E(S)$ is the expected number of lineages at the indicated sample size as calculated from their abundance distributions. Error bars represent $\pm 2 S D$ of the $E(S)$. Curve endpoints are observed number of lineages and therefore have no error estimation. The broken line corresponds to the reference sample size (smallest among the samples) that is the largest sample size at which all samples can be compared. 
while only six of the rare pathotypes were recovered from all regions. The latter observation could be an artifact of the few individuals (mean of 1.5) obtained for these pathotypes. All common pathotypes were found in the northeast, and there was moderate ( 0.30 to 0.40 ) pathotype overlap across sites and seasons when the rare pathotypes were excluded from the analysis (Tables 4 and 5).

The local Thai cultivar HY71 was resistant at all sites, with the exception of Phrae, where intermediate susceptibility was observed. However, attempts to isolate the fungus from HY71 failed. It was resistant to all isolates in common lineages except lineages 7 and 22 in the northeast and lineages 2 and 7 in the northern population under controlled inoculations (Table 6). The widely grown cultivar KDML105 was susceptible to a large number of pathotypes and isolates from different MGR586 lineages. All common pathotypes were recovered from the local cultivars KDML105, RD6, RD23, and KTH17, which are susceptible throughout northern and northeastern Thailand (Table 1).

Virulence diversity and distribution. The number of virulences per pathotype and per isolate varied across host type, with pathotypes collected from indigenous hosts tending to have fewer virulences than those collected from exotic hosts (Table 3). For the entire population, the mean number of virulences per pathotype was 7.6 and per isolate was 7.3. The mean numbers of virulences per pathotype and per isolate in the northeastern sites Khon Kaen and Ubon were the same. However, Phrae was significantly higher than the Sanpatong site. The mean number of virulences per pathotype and per isolate differed among sampling seasons. The distribution of the number of virulences (0 to 16) among all isolates was not normal according to the Anderson-Darling test (44), and the distribution was significantly $(P=0.05)$ skewed below the 8.5 expected if the number of virulences was allocated randomly across isolates with the observed mean of 7.3 and mode of 6 .

Among the common pathotypes, there was no strong relationship between the number of virulences in a pathotype and its frequency of detection (Table 2). There was a tendency for the more common pathotypes to have fewer virulences than the uncommon pathotypes (Fig. 3), and

Table 3. Pathotypic diversity and virulence complexity of Pyricularia grisea on different pathotype group, hosts of origin, sites, and seasons in Thailand, based on their compatibility with 15 nearisogenic lines

\begin{tabular}{llllll}
\hline Population & $\begin{array}{l}\text { No. of } \\
\text { isolates }\end{array}$ & $\begin{array}{l}\text { No. of } \\
\text { pathotype }\end{array}$ & $\mathbf{D}^{\prime \mathbf{w}}$ & $\mathbf{C p}^{\mathbf{x}}$ & $\mathbf{C i}^{\mathbf{y}}$ \\
\hline $\begin{array}{l}\text { Entire population } \\
\text { Host }\end{array}$ & 527 & 175 & 0.68 & 7.63 & 7.32 \\
$\quad$ Exotic hosts & 245 & 123 & 0.78 & $7.80 \mathrm{a}^{\mathbf{z}}$ & $7.49 \mathrm{a}$ \\
$\quad$ Indigenous & 282 & 94 & 0.68 & $7.29 \mathrm{a}$ & $7.18 \mathrm{a}$ \\
Site & & & & & \\
KKN & 113 & 53 & 0.70 & $7.89 \mathrm{~b}$ & $7.05 \mathrm{ab}$ \\
UBN & 197 & 94 & 0.78 & $7.78 \mathrm{~b}$ & $7.63 \mathrm{bc}$ \\
SPT & 94 & 50 & 0.77 & $6.72 \mathrm{a}$ & $6.36 \mathrm{a}$ \\
PRE & 76 & 48 & 0.84 & $8.02 \mathrm{~b}$ & $7.93 \mathrm{c}$ \\
RBR & 47 & 27 & 0.81 & $7.59 \mathrm{ab}$ & $7.47 \mathrm{bc}$ \\
Season & & & & & \\
1993 wet & 122 & 77 & 0.84 & $8.21 \mathrm{~b}$ & $8.06 \mathrm{~b}$ \\
1994 wet & 208 & 82 & 0.72 & $6.89 \mathrm{a}$ & $6.67 \mathrm{a}$ \\
1994 dry & 197 & 87 & 0.89 & $7.82 \mathrm{~b}$ & $7.56 \mathrm{~b}$ \\
\hline
\end{tabular}

" Phenotypic diversity index: $\mathrm{D}^{\prime}=$ normalized Shannon's index.

${ }^{x}$ Equivalent to virulence complexity $(\mathrm{Cp}=$ number of virulences per pathotype) (2).

${ }^{\mathrm{y}}$ Equivalent to virulence complexity $(\mathrm{Ci}=$ number of virulences per isolate) (2).

${ }^{\mathrm{z}}$ Mean values with different letters within a column are significantly different as determined by Fisher's protected least significant difference (FPLSD) procedure $(P \leq 0.05)$ using criteria of host, site, and season.

Table 4. Rogers index of proportional overlap for pathotypes of Pyricularia grisea isolates collected from five locations in 1993 to 1994, based on reaction of near-isogenic lines

\begin{tabular}{lccccc}
\hline & \multicolumn{5}{c}{ Locations $^{\mathbf{y}}$} \\
\cline { 2 - 6 } & KKN & UBN & SPT & PRE & RBR \\
\hline KKN & $\ldots$ & $0.39^{z}$ & 0.26 & 0.40 & 0.40 \\
UBN & $\ldots$ & $\ldots$ & 0.37 & 0.35 & 0.41 \\
SPT & $\ldots$ & $\ldots$ & $\ldots$ & 0.36 & 0.40 \\
PRE & $\ldots$ & $\ldots$ & $\ldots$ & $\ldots$ & 0.21 \\
\hline
\end{tabular}

${ }^{y} \mathrm{KKN}=$ Khon Kaen Rice Experimental Station, UBN $=$ Ubon Rice Research Center, PRE $=$ Phrae Rice Research Center, SPT = Sanpatong Rice Experimental Station, RBR = Ratchaburi Rice Experimental Station.

${ }^{\mathrm{z}}$ Ranges from 0 to 1.0. Value is 0 when samples are identical and 1.0 when samples share no pathotypes in common. their distribution was skewed similarly to that for the overall population. Thus, there was a tendency for isolates with fewer virulences to predominate in the population.

Partitioning the population by MGR586 lineage allows us to ask how virulence and avirulence are distributed within different genetic backgrounds. All common lineages had high pathotype diversity, and these were fairly evenly represented, as indicated by the high Shannon diversity indices (Table 7). Lineage 14 is richer in pathotypes than other lineages with 28 or more isolates (Fig. 2D), but several other common lineages $(1,3,12$, and 19) had even higher absolute diversity values. The range of virulences per isolate by lineage (5.20 to 9.08 , or $42 \%$ of the theoretical maximum) was more than double that observed by host or season. The number of virulences per isolate is less than or equal to the number of virulences per pathotype in all but four of the 15 common lineages, indicating that isolates with fewer virulences predominate within most of the lineages. Overall, the number of virulences per isolate was less than the number of virulences per pathotype for the common lineages, again indicating the predominance of isolates from pathotypes with fewer virulences. Lineage 14, which had the greatest number of pathotypes, also had the fewest virulences per pathotype and per isolate (Table 7). In the rare lineages, isolates from pathotypes with the greatest number of virulences predominated. Between rare and common lineages, therefore, we observed an inverse relationship between frequency and virulence complexity.

Analysis of the association of virulences by season and site yielded only one case (KKN, 1993) out of 11 for which the hypothesis of random association among virulences could not be rejected at the $5 \%$ level (data not shown). The hypothesis of random association among virulences could not be rejected for four lineage-site combinations, but it was rejected for 14 other lineage-site combinations (Table 8). The pairwise associations of virulence for $P i$ genes with $\mathrm{CO} 39$ background, with the exception of $P i z-5$, showed higher than

Table 5. Rogers index of proportional overlap for pathotype of Pyricularia grisea isolates collected in the 1993, 1994 wet season, and 1994 dry season

\begin{tabular}{lccc}
\hline \multicolumn{4}{l}{ Rogers index of common pathotypes } \\
\hline Year & $\mathbf{1 9 9 3}$ & $\mathbf{1 9 9 4 W}$ & $\mathbf{1 9 9 4 D}$ \\
\hline 1993 & $\ldots$ & $0.29^{\mathrm{z}}$ & 0.37 \\
1994W & $\ldots$ & $\ldots$ & 0.34 \\
No. of & 49 & 120 & 111 \\
isolate & & & \\
\hline
\end{tabular}

${ }^{\text {y }}$ Common pathotype $=$ those represented by eight or more isolates.

${ }^{\mathrm{z}}$ Ranges from 0 to 1.0 . Value is 0 when samples are identical and 1.0 when samples share no pathotypes in common. 
expected associations, while the associations of virulence for $P i$ genes in LTH NILs were as expected. Virulences for $P i$ 1, $P i 1^{L A C}, P i z-5$, and $P i t a^{2}$ were detected in low frequency at all sites (Table 9).

Lineage-virulence relationship. Seven of the 10 most well-represented lineages (>20 isolates tested per lineage) were incompatible with one or more NILs. These were always $P i 1$ or $P i z-5$. Although some isolates in lineages $2,7,8,12$, and 22 had compatibility with $P i 1$ or $P i z-5$, no isolate tested combined compatibility with both. No lineage-level incompatibility was observed for any common lineages with the LTH NILs. Rare lineages, viewed as a set, showed similar patterns of compatibility to the NILs as the common lineages and common pathotypes: very low compatibility with $P i 1, P i z-5, P i b$, and $P i 4^{a}$ and $P i$ $t a^{2}$. Some resistance genes $\left(P i-1(t)^{T T P}, P i\right.$ $\left.4^{a}, P i 4^{b}(t), P i t a^{2}, P i b, P i k^{p}\right)$ showed marked differential reaction across lineages. Some lineages exhibited strong differential compatibility or incompatibility with several avirulence genes (e.g., lineages 21 , 38,44 , and 46) (data not shown). No combination of resistance genes provides combined resistance against all of the lineages in Thailand. However, combinations of $P i$ 1 and $P i z-5$ seem to be effective against almost all lineages in the northern and northeastern populations, with the exception of lineages 7 and 12 in the north and 7 in the northeast (Table 9). Pi $t a^{2}$, which is broadly effective against common pathotypes (Table 2), does not appear to be as effective when assessed from a lineage perspective (Table 9).

\section{DISCUSSION}

An understanding of the regional distribution of pathotypes and the frequency of

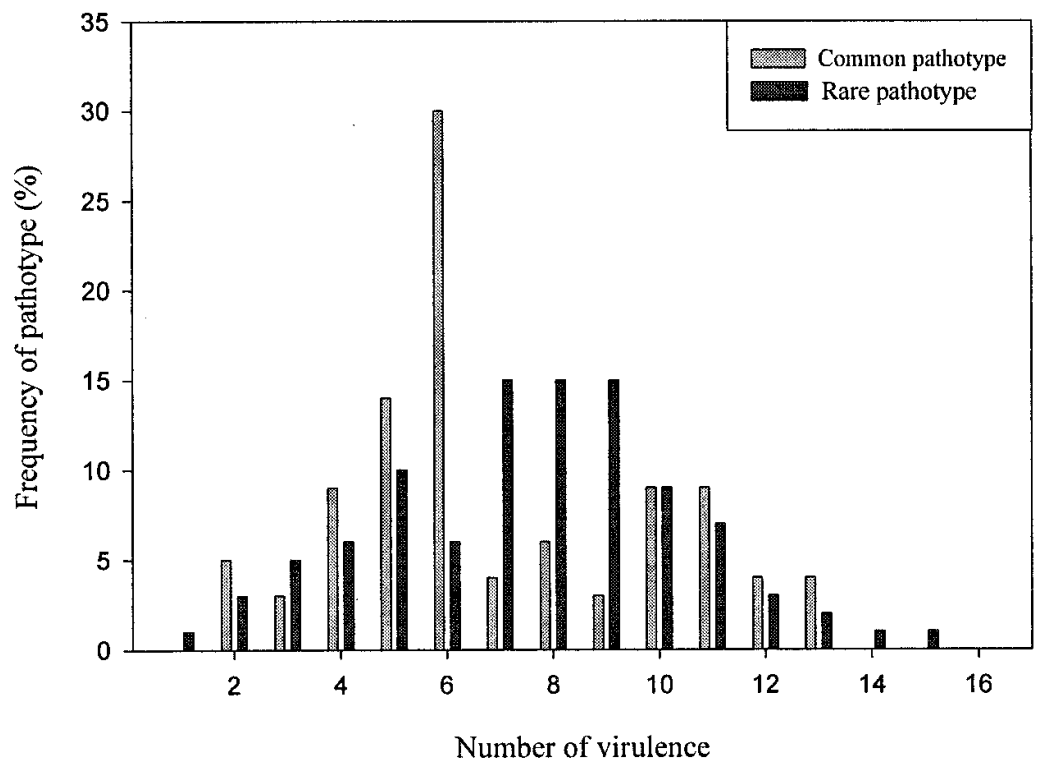

Fig. 3. Abundance distributions of inferred virulence genes (avr-) in the overall Thailand Pyricularia grisea population, as determined by compatibility with rice lines near-isogenic for major resistance genes.

Table 6. Composite pathotype of isolates within common lineages from northeast, north, and central Thailand

\begin{tabular}{|c|c|c|c|c|c|c|c|c|c|c|c|c|c|}
\hline \multirow{2}{*}{$\begin{array}{l}\text { MGR586 } \\
\text { lineage }\end{array}$} & \multicolumn{11}{|c|}{ Differential near-isogenic lines (NILs) } & \multirow[b]{2}{*}{$\mathbf{N p}^{\mathbf{u}}$} & \multirow[b]{2}{*}{$\mathrm{Ni}$} \\
\hline & $P i-1$ & $P i-1^{L A C}$ & $P i-1^{T T P}$ & $P i z-5$ & $P i-4^{a}$ & $P i-4^{b}$ & NILs $^{\text {s }}$ & $P i-t a^{2}$ & NILst $^{t}$ & HY71 & KDML105 & & \\
\hline \multicolumn{14}{|l|}{ Northeast } \\
\hline 1 & $\mathrm{~S}^{\mathrm{w}}$ & $\mathrm{S}$ & $\mathrm{S}$ & $\mathrm{R}$ & $\mathrm{S}$ & $\mathrm{S}$ & $\mathrm{S}$ & $\mathrm{S}$ & $\mathrm{S}$ & $\mathrm{R}$ & $\mathrm{S}$ & 11 & 12 \\
\hline 2 & $\mathrm{R}$ & $\mathrm{R}$ & $\mathrm{S}$ & $\mathrm{R}$ & $S$ & $S$ & $\mathrm{~S}$ & $\mathrm{~S}$ & $\mathrm{~S}$ & $\mathrm{R}$ & $S$ & 16 & 24 \\
\hline 3 & $\mathrm{R}$ & $\mathrm{S}$ & $\mathrm{R}$ & $\mathrm{S}$ & $S$ & $S$ & $\mathrm{~S}$ & $\mathrm{R}$ & $\mathrm{S}$ & $\mathrm{R}$ & $S$ & 9 & 9 \\
\hline 5 & $\mathrm{~S}$ & $\mathrm{~S}$ & $\mathrm{~S}$ & $\mathrm{R}$ & $\mathrm{S}$ & $\mathrm{S}$ & $\mathrm{S}$ & $\mathrm{S}$ & $\mathrm{S}$ & $\mathrm{R}$ & $\mathrm{S}$ & 14 & 17 \\
\hline 7 & $\mathrm{~S}$ & $\mathrm{~S}$ & $\mathrm{~S}$ & $\mathrm{~S}$ & $\mathrm{~S}$ & $S$ & $\mathrm{~S}$ & $\mathrm{R}$ & $\mathrm{S}$ & $\mathrm{S}$ & $\mathrm{S}$ & 13 & 16 \\
\hline 8 & $\mathrm{~S}$ & $\mathrm{R}$ & $\mathrm{S}$ & $\mathrm{R}$ & $S$ & $\mathrm{~S}$ & $\mathrm{~S}$ & $\mathrm{R}$ & $\mathrm{S}$ & $\mathrm{R}$ & $\mathrm{S}$ & 20 & 31 \\
\hline 15 & $\mathrm{R}$ & $\mathrm{R}$ & $\mathrm{S}$ & $\mathrm{R}$ & $\mathrm{S}$ & $S$ & $\mathrm{~S}$ & $\mathrm{~S}$ & $\mathrm{~S}$ & $\mathrm{R}$ & $S$ & 25 & 48 \\
\hline 21 & $\mathrm{R}$ & $\mathrm{R}$ & $\mathrm{S}$ & $\mathrm{R}$ & $\mathrm{R}$ & $\mathrm{R}$ & $\mathrm{S}$ & $\mathrm{S}$ & $\mathrm{S}$ & $\mathrm{R}$ & $\mathrm{S}$ & 9 & 14 \\
\hline 22 & $\mathrm{~S}$ & $S$ & $\mathrm{~S}$ & $\mathrm{R}$ & $\mathrm{S}$ & $\mathrm{S}$ & $\mathrm{S}$ & $\mathrm{R}$ & $\mathrm{S}$ & $\mathrm{S}$ & $\mathrm{S}$ & 15 & 22 \\
\hline 43 & $\mathrm{R}$ & $\mathrm{R}$ & $\mathrm{S}$ & $\mathrm{R}$ & $\mathrm{S}$ & $\mathrm{S}$ & $\mathrm{S}$ & $\mathrm{R}$ & $\mathrm{S}$ & $\mathrm{R}$ & $\mathrm{S}$ & 20 & 34 \\
\hline 47 & $\mathrm{~S}$ & $\mathrm{~S}$ & $\mathrm{~S}$ & $\mathrm{R}$ & $\mathrm{S}$ & $S$ & $\mathrm{~S}$ & $\mathrm{~S}$ & $\mathrm{~S}$ & $\mathrm{R}$ & $S$ & 9 & 11 \\
\hline 48 & $\mathrm{R}$ & $\mathrm{S}$ & $\mathrm{R}$ & $\mathrm{R}$ & $\mathrm{S}$ & $S$ & $\mathrm{~S}$ & $\mathrm{~S}$ & $S$ & $\mathrm{R}$ & $S$ & 7 & 11 \\
\hline Rare $^{\mathrm{x}}$ & $\mathrm{S}$ & $\mathrm{S}$ & $\mathrm{S}$ & $\mathrm{R}$ & $\mathrm{S}$ & $S$ & $\mathrm{~S}$ & $\mathrm{R}$ & $\mathrm{S}$ & $\mathrm{S}$ & $S$ & 29 & 44 \\
\hline \multicolumn{14}{|l|}{ North } \\
\hline 2 & $\mathrm{~S}$ & $\mathrm{R}$ & $\mathrm{R}$ & $\mathrm{R}$ & $S$ & $\mathrm{~S}$ & $\mathrm{~S}$ & $\mathrm{~S}$ & $\mathrm{~S}$ & $\mathrm{~S}$ & $\mathrm{~S}$ & 17 & 21 \\
\hline 7 & $\mathrm{~S}$ & $\mathrm{~S}$ & $\mathrm{~S}$ & $\mathrm{~S}$ & $\mathrm{~S}$ & $\mathrm{~S}$ & $\mathrm{~S}$ & $\mathrm{~S}$ & $\mathrm{~S}$ & $\mathrm{~S}$ & $\mathrm{~S}$ & 12 & 15 \\
\hline 12 & $\mathrm{~S}$ & $S$ & $\mathrm{~S}$ & $\mathrm{~S}$ & $\mathrm{~S}$ & $S$ & $\mathrm{~S}$ & $\mathrm{~S}$ & $\mathrm{~S}$ & $\mathrm{R}$ & $\mathrm{S}$ & 12 & 13 \\
\hline 14 & $\mathrm{R}$ & $\mathrm{R}$ & $\mathrm{S}$ & $\mathrm{R}$ & $\mathrm{S}$ & $S$ & $\mathrm{~S}$ & $\mathrm{~S}$ & $S$ & $\mathrm{R}$ & $\mathrm{S}$ & 26 & 28 \\
\hline 27 & $\mathrm{R}$ & $\mathrm{R}$ & $\mathrm{S}$ & $\mathrm{R}$ & $\mathrm{S}$ & $\mathrm{S}$ & $\mathrm{S}$ & $\mathrm{R}$ & $\mathrm{S}$ & $\mathrm{R}$ & $\mathrm{S}$ & 18 & 21 \\
\hline 33 & $\mathrm{R}$ & $\mathrm{R}$ & $\mathrm{R}$ & $\mathrm{R}$ & $\mathrm{S}$ & $\mathrm{S}$ & $\mathrm{S}$ & $\mathrm{S}$ & $S$ & $\mathrm{R}$ & $S$ & 12 & 21 \\
\hline 38 & $\mathrm{R}$ & $\mathrm{R}$ & $\mathrm{R}$ & $\mathrm{R}$ & $\mathrm{S}$ & $\mathrm{S}$ & $\mathrm{S}$ & $\mathrm{R}$ & $\mathrm{S}$ & $\mathrm{R}$ & $\mathrm{S}$ & 7 & 8 \\
\hline Rare $^{y}$ & $\mathrm{R}$ & $\mathrm{R}$ & $\mathrm{S}$ & $\mathrm{R}$ & $S$ & $S$ & $\mathrm{~S}$ & $\mathrm{~S}$ & $S$ & $\mathrm{R}$ & $S$ & 24 & 32 \\
\hline \multicolumn{14}{|l|}{ Central } \\
\hline 2 & $\mathrm{R}$ & $\mathrm{R}$ & $\mathrm{R}$ & $\mathrm{R}$ & $\mathrm{S}$ & $\mathrm{R}$ & $\mathrm{S}$ & $\mathrm{S}$ & $\mathrm{S}$ & $\mathrm{R}$ & $\mathrm{S}$ & 7 & 8 \\
\hline 5 & $\mathrm{R}$ & $\mathrm{R}$ & $\mathrm{R}$ & $\mathrm{R}$ & $\mathrm{S}$ & $\mathrm{R}$ & $\mathrm{S}$ & $\mathrm{R}$ & $\mathrm{S}$ & $\mathrm{R}$ & $S$ & 7 & 8 \\
\hline Rare $^{\mathrm{z}}$ & $\mathrm{R}$ & $\mathrm{R}$ & $\mathrm{R}$ & $\mathrm{R}$ & $\mathrm{S}$ & $\mathrm{R}$ & $\mathrm{S}$ & $\mathrm{R}$ & $\mathrm{S}$ & $\mathrm{R}$ & $S$ & 20 & 30 \\
\hline
\end{tabular}

s NIL-CO39: $P i-3, P i-4 a^{P K T}, P i-4 a^{T T P}, \mathrm{CO} 39$.

${ }^{t}$ NIL-Lijiangxintuanheigu: $P i-k^{m}, P i-t a, P i-b, P i-k^{p}, P i-k$.

u Number of pathotype.

${ }^{v}$ Number of isolate.

${ }^{\mathrm{w}} \mathrm{S}=>5 \%$ of isolates within lineage were compatible to NILs; $\mathrm{R}=<5 \%$ of isolates within lineage were compatible to the NILs.

x 19 rare lineages.

y 18 rare lineages.

z 10 rare lineages. 
different avirulence genes can be useful guides to disease resistance breeding programs. The $P$. grisea populations in Thailand show high pathotypic diversity across the regions studied. This diversity is moderately consistent across sites; but it varies with season, and its estimate is affected by whether samples originate from indigenous or exotic hosts. The rarity of many pathotypes indicates that a large number of pathotypes was not detected in these samples. As the pathotypes in this study have been determined by the interaction between rices lines near-isogenic for major resistance genes, and as there appears to be a gene-for-gene relationship between major host resistance genes and pathogen avirulence genes in this pathosystem (42), the observed high pathotypic diversity reflects significant allelic diversity in avirulence genes. Indeed, compatibility was detected in the pathogen population for every resistance gene included in this study.

In some areas where rice, and presumably $P$. grisea, have been introduced within the last few hundred years, pathotype diversity has been reported to be low $(24,38,48)$. In contrast, the highly diverse $P$. grisea populations in Thailand are probably very old, as the oldest archaeological evidence for rice cultivation in the region dates to about 11,000 B.C. (6). The continued cultivation of traditional cultivars and their derivatives suggests that the populations may not have been subjected recently to the extreme bottlenecks imposed by the introduction and widespread cultivation of exotic materials containing broad-spectrum resistance genes. Thus, these populations may offer a glimpse into the composition of $P$. grisea populations before the advent of modern international plant breeding that disseminated multiple major, and locally novel, resistance genes. They may also reflect pathotype diversity found over the millions of hectares of rainfed rice grown worldwide under similar conditions.

We expect dominant pathotypes in a population to be those that are best adapted to the local environment and/or compatible with commonly grown cultivars. The greater number of pathotypes recovered from exotic versus indigenous host lines, and their individual rarity, suggest that the resistance genes in exotic lines may act as filters against common pathotypes. That is, samples from local cultivars will tend to yield only the most abundant compatible pathotypes, even though others may be present that may or may not be compatible with the local cultivars. If exotic lines are incompatible with the most common pathotypes, then the likelihood of sampling less common pathotypes increases. Thus, for population characterization in areas where populations may be pathotypically diverse, samples should be collected from exotic as well as from local materials to increase the likelihood that less-welladapted variants are detected and to re- move one bias affecting estimates of pathotypic diversity. Obviously, these rare types are potential sources of resistance breakdown, should novel resistance genes be deployed.
Despite the high pathotype diversity, the $P i l$ set, $P i z-5$, and to a lesser extent, $P i$ $t a^{2}$, were effective against most isolates. Where compatibility with $P i 1$ and $P i z-5$ occurred within a lineage or a site, the

Table 7. Pathotypic diversity and virulence complexity of common lineages of Pyricularia grisea collected from five sites in 1993 to 1994, based on their compatibility within near-isogenic lines

\begin{tabular}{|c|c|c|c|c|c|}
\hline MGR586 lineage & $\begin{array}{l}\text { No. of } \\
\text { isolate }\end{array}$ & $\begin{array}{c}\text { No. of } \\
\text { pathotype }\end{array}$ & $\mathbf{D}^{\prime} \mathbf{u}$ & $\mathrm{Cp}^{\mathbf{v}}$ & $\mathrm{Ci}^{\mathbf{w}}$ \\
\hline 2 & 53 & 31 & 0.79 & $7.39 \mathrm{~b}-\mathrm{e}$ & $6.72 b c$ \\
\hline 15 & 49 & 25 & 0.70 & $7.40 \mathrm{~b}-\mathrm{e}$ & $6.71 \mathrm{bc}$ \\
\hline 43 & 42 & 24 & 0.77 & $7.79 \mathrm{~b}-\mathrm{e}$ & $7.69 \mathrm{c}-\mathrm{e}$ \\
\hline 8 & 32 & 20 & 0.81 & $6.85 \mathrm{a}-\mathrm{d}$ & $6.44 \mathrm{ab}$ \\
\hline 7 & 31 & 23 & 0.84 & $7.83 \mathrm{~b}-\mathrm{e}$ & $7.16 \mathrm{~b}-\mathrm{d}$ \\
\hline 14 & 30 & 26 & 0.94 & $5.58 \mathrm{a}$ & $5.20 \mathrm{a}$ \\
\hline 5 & 28 & 19 & 0.84 & $8.32 \mathrm{~b}-\mathrm{e}$ & $7.54 \mathrm{~b}-\mathrm{e}$ \\
\hline 33 & 25 & 13 & 0.59 & 7.46 a-e & $6.76 \mathrm{~b}-\mathrm{d}$ \\
\hline 27 & 22 & 18 & 0.91 & $6.67 \mathrm{a}-\mathrm{c}$ & $6.73 \mathrm{~b}-\mathrm{d}$ \\
\hline 22 & 22 & 15 & 0.83 & $8.93 \mathrm{e}$ & $8.68 \mathrm{e}$ \\
\hline 21 & 15 & 9 & 0.70 & $6.00 \mathrm{ab}$ & $5.93 \mathrm{ab}$ \\
\hline 1 & 13 & 12 & 0.96 & $8.92 \mathrm{de}$ & $9.08 \mathrm{e}$ \\
\hline 12 & 13 & 12 & 0.96 & $8.50 \mathrm{~b}-\mathrm{e}$ & $8.31 \mathrm{c}-\mathrm{e}$ \\
\hline 48 & 12 & 8 & 0.77 & $8.87 \mathrm{c}-\mathrm{e}$ & $9.08 \mathrm{e}$ \\
\hline 19 & 11 & 11 & 1 & $6.18 \mathrm{ab}$ & $6.18 \mathrm{a}-\mathrm{c}$ \\
\hline 47 & 11 & 9 & 0.87 & $7.54 \mathrm{c}-\mathrm{e}$ & $8.78 \mathrm{~b}-\mathrm{e}$ \\
\hline 3 & 9 & 9 & 1 & 7.44 a-e & $7.44 \mathrm{~b}-\mathrm{e}$ \\
\hline 38 & 8 & 7 & 0.92 & $8.71 \mathrm{~b}-\mathrm{e}$ & $8.87 \mathrm{de}$ \\
\hline Common lineages $\mathrm{x}$ & 426 & 148 & 0.69 & $7.53^{\mathrm{a}^{*} \mathrm{y}}$ & $7.09 \mathrm{a}^{\mathrm{*}}$ \\
\hline Rare lineages ${ }^{\mathrm{z}}$ & 72 & 41 & 0.82 & $8.27^{\mathrm{a}^{*}}$ & $8.51^{\mathrm{b} *}$ \\
\hline All lineages & 498 & 168 & 0.68 & 7.66 & 7.31 \\
\hline
\end{tabular}

" Phenotypic diversity indices: $\mathrm{D}^{\prime}=$ normalized Shannon index.

${ }^{v}$ Equivalent to virulence complexity $(\mathrm{Cp}=$ number of virulences per pathotype) (2).

${ }^{\mathrm{w}}$ Equivalent to virulence complexity $(\mathrm{Ci}=$ number of virulences per isolate $)(2)$.

$x 18$ lineages.

y Mean values with different superscript letters within a column are significantly different as determined by Fisher's protected least significant difference (FPLSD) procedure $(P \leq 0.05)$. * denoted for the comparison between common and rare lineage.

z 31 lineages.

Table 8. Associations among putative virulence loci within lineage of Pyricularia grisea (clone corrected isolates) from five trap nursery sites in Thailand in 1993 to 1994, based on the multilocus analysis

\begin{tabular}{lcccccc}
\hline $\begin{array}{l}\text { MGR586 } \\
\text { Lineage }\end{array}$ & Site $^{\mathbf{u}}$ & $\begin{array}{c}\text { No. of } \\
\text { pathotype }^{\mathbf{v}}\end{array}$ & $\mathbf{V}(\mathbf{o})^{\mathbf{w}}$ & $\mathbf{V}(\mathbf{e})^{\mathbf{x}}$ & $\mathbf{I}_{\mathbf{A}}^{\mathbf{y}}$ & $\mathbf{L}^{\mathbf{z}}$ \\
\hline 1 & UBN & 10 & 3.68 & 2.63 & 0.40 & 3.91 \\
2 & UBN & 14 & 6.22 & 2.65 & 1.35 & 3.60 \\
& SPT & 14 & 5.10 & 2.58 & 0.98 & 3.47 \\
3 & UBN & 9 & 5.43 & 2.44 & 1.22 & 3.67 \\
5 & KKN & 7 & 1.85 & 1.48 & 0.25 & 2.05 \\
7 & KKN & 8 & 3.21 & 1.67 & 0.32 & 2.28 \\
& PRE & 10 & 5.79 & 2.93 & 0.97 & 4.54 \\
8 & UBN & 18 & 5.92 & 2.48 & 1.38 & 3.12 \\
12 & SPT & 7 & 5.91 & 2.21 & 1.67 & 3.50 \\
14 & SPT & 22 & 5.86 & 2.42 & 1.42 & 2.91 \\
15 & KKN & 22 & 3.53 & 2.50 & 0.41 & 3.03 \\
21 & UBN & 7 & 1.66 & 1.46 & 0.13 & 2.02 \\
22 & UBN & 16 & 3.73 & 2.42 & 0.54 & 3.13 \\
27 & PRE & 18 & 5.31 & 2.54 & 1.09 & 3.20 \\
33 & SPT & 12 & 3.62 & 2.45 & 0.48 & 3.40 \\
38 & PRE & 7 & 1.75 & 1.35 & 0.29 & 1.80 \\
43 & UBN & 15 & 3.67 & 2.12 & 0.73 & 2.70 \\
& KKN & 7 & 3.86 & 1.92 & 1.01 & 2.88 \\
\hline
\end{tabular}

" UBN = Ubon Rice Research Center, KKN = Khon Kaen Rice Experimental Station, PRE = Phrae Rice Research Center, SPT = Sanpatong Rice Experimental Station, RBR = Ratchaburi Rice Experimental Station.

${ }^{v}$ Only one isolate per pathotype in a lineage included in the analysis.

${ }^{\mathrm{w}}$ Observed variance in the samples.

${ }^{\mathrm{x}}$ Expected variance in the samples.

${ }^{y}$ Index of association.

${ }^{\mathrm{z}}$ Upper $95 \%$ confidence limit for the observed variance. If $\mathrm{L}>\mathrm{V}(\mathrm{o})$, null hypothesis of random association among virulence loci could not be rejected, if $\mathrm{L}<\mathrm{V}(\mathrm{o})$, null hypothesis was rejected (5). 
pathotypes were represented by only one to a very few isolates, and in no case was an isolate observed with compatibility to both genes. Compatibility with these resistance genes was distributed across a number of MGR586 lineages, unlike reports from other areas, where $P i z-5$ compatibility was restricted to a single lineage $(7,8)$. In other studies, $P i 1$ and $P i z-5$ have been identified as having broad resistance spectra, and combining them with other carefully selected major genes has been proposed as a means of achieving durable resistance in target populations $(7,49)$. The effectiveness of these genes alone, and the absence (or rarity, below detection levels) of isolates with compatibility to both genes discovered in studies from the Philippines, Colombia, and now Thailand, suggest that simultaneous loss of function of the corresponding avirulence genes in nature occurs very rarely, if ever. Thus, simultaneous virulence may carry a significant fitness penalty. However, if $P i \quad l$ and $P i z-5$ have not been widely deployed in these study regions, there would not necessarily be a selective advantage for the nonfunctional avirulence genes to increase in frequency in the populations. Thus, the observed low frequency of dual compatibility might simply be a historical consequence of local host selection and not be predictive of any evolutionary limitations. Research into fitness penalties imposed by compatibility with these genes is needed.

If compatibility with $P i 1$ and $P i z-5$ represents extreme cases of low fitness associated with loss of avirulence, do data from this study suggest that this may be a general phenomenon associated with most avirulence genes? Within the overall population, and regardless of how the population is partitioned (host of origin, site, or season), the observation that common pathotypes always have fewer virulences than rare pathotypes is consistent with a fitness disadvantage to accumula- tion of virulence. Within some lineages, however, there is a slightly different relationship, although this remains consistent with the hypothetical fitness penalty for accumulating virulence. For the most common, and presumably the most fit, lineages, the trend toward fewer virulences per isolate compared with per pathotype is maintained. However, for the rarer lineages, those isolates with greater numbers of virulences are more frequently encountered.

This analysis assumes that all alleles confer equal fitness penalty when they lose their avirulence function. All isolates were compatible with CO39, which carries $P i a$, and it seems unlikely that this would occur if a significant penalty were associated with Pi a compatibility. There are markedly different frequencies of avirulence corresponding to the different resistance genes. These differences may, in part, reflect different fitness penalties. But this interpretation may be confounded by an adaptive advantage conferred by specific compatibility with one or more widely grown cultivars in the region that produces genetic hitchhiking effects.

In asexual populations, virulence associations can arise as a result of chance or selection, and these mechanisms cannot be distinguished (2). A direct adaptive advantage is probably not important for most of the avirulence genes used in this study in Thailand, since all avirulence genes are not functional in many isolates and in common pathotypes compatible with widely grown cultivars. Virulence present in pathotypes compatible with all widely grown cultivars has historically been considered "unnecessary." The presence of apparently unnecessary virulences in many common pathotypes suggests that not all avirulence genes confer a significant or detectable fitness penalty as a consequence of loss of function. It is noteworthy that for the barley powdery mildew pathogen (Erysiphe graminis) in Europe, no significant deleterious effect of unnecessary virulence alleles could be detected. Over a 5-year period during which the principal deployed resistance genes changed greatly, the average number of virulences remained fairly constant in the populations (2).

The observed disequilibrium among inferred avirulence genes in this population may have resulted from linkage between avirulence genes and/or other traits conferring selective advantage, and/or selective advantage conferred by specific adaptation to local cultivars. In largely or completely asexual populations, selection should favor disequilibrium. Little is known about the location of avirulence genes on $P$. grisea chromosomes, and no evidence for a selective advantage for a particular avirulence gene was seen in this study. In a randomly mating population, we would expect to see avirulence genes in random association in the absence of selection. However, even under such conditions, some avirulence genes still could "hitchhike" with genes conferring an advantage and yield disequilibrium.

Pair-wise analysis of virulence associations shows significant positive association within the Pi ta complex and to a lesser extent within the Pi 1 complex. Differential reactions leave no doubt that the genes within the Pi 1 and the Pi ta complexes are not simply alleles. Since NILs in each complex originated from a single cultivar (27), the observed positive associations are consistent with these being gene clusters, or possibly families. Negative associations of virulence expected between $P i 1$ and $P i$ $z-5(7,49)$ were weak at best. However, this association is difficult to interpret because of the very low frequency of compatibility in the populations.

The detection of sexually fertile isolates of $P$. grisea from Thailand has led to some speculation that sexual recombination may play a role in generating genotypic diver-

Table 9. Percentage of Pyricularia grisea isolates compatible with Pi genes (diagonal), observed (below diagonal), and expected percentage (above diagonal) compatible for diallel pairs of $P i$ genes among five sites in Thailand ${ }^{\mathrm{z}}$

\begin{tabular}{|c|c|c|c|c|c|c|c|c|c|c|c|c|c|c|c|c|}
\hline & \multicolumn{16}{|c|}{ Percent isolates compatible with $P i$ genes } \\
\hline & $P i 1$ & $P i 1^{L A C}$ & $P i 1^{T T P}$ & $P i z^{5}$ & $P i 3$ & $P i 4^{a}(t)$ & $\begin{array}{c}P i \\
4^{a}(t)^{P K T}\end{array}$ & $\begin{array}{c}P i \\
4^{a}(t)^{T T P}\end{array}$ & $P i 4^{b}(t)$ & Pia & Pi-km & $P i-t a$ & $P i-t a^{2}$ & $P i-b$ & Pi-kp & $P i-k$ \\
\hline$P i 1$ & 5.9 & 0.2 & 0.7 & 0.07 & 3.3 & 2.1 & 3.3 & 2.6 & 1.6 & 5.8 & 4.8 & 4.7 & 0.5 & 3.1 & 4.1 & 5.8 \\
\hline$P i 1^{L A C}$ & $1.1^{*}$ & 4.2 & 0.5 & 0.05 & 2.3 & 1.5 & 2.3 & 1.9 & 1.2 & 4.1 & 3.4 & 3.4 & 0.3 & 2.2 & 3.0 & 4.1 \\
\hline$P i l^{T T P}$ & $5.1^{*}$ & 1.7 & 11.4 & 0.1 & 6.4 & 4.1 & 6.4 & 5.1 & 3.2 & 11.2 & 9.2 & 9.1 & 0.9 & 6.0 & 8.1 & 11.1 \\
\hline$P i z^{5}$ & 0 & 0.4 & 0 & 1.14 & 0.6 & 0.4 & 0.6 & 0.5 & 0.3 & 1.1 & 0.9 & 0.9 & 0.1 & 0.6 & 0.8 & 1.1 \\
\hline $\mathrm{Pi} 3$ & 4.9 & 3.8 & 10.2 & 0.9 & 55.8 & 20 & 31.2 & 24.8 & 15.6 & 54.8 & 45.2 & 44.6 & 4.6 & 29.6 & 39.3 & 54.5 \\
\hline$P i 4^{a}(t)$ & 4.2 & 3.8 & 8 & $0.8^{*}$ & $35 * *$ & 35.9 & 20.1 & 15.9 & 10 & 35.3 & 29.1 & 28.7 & 3.0 & 19 & 25.3 & 35.1 \\
\hline$P i 4^{a}(t)^{P K T}$ & 4.7 & 3.8 & 10.2 & 0.8 & $49.7 * *$ & $35 * *$ & 56 & 24.9 & 15.7 & 55 & 45.4 & 44.8 & 4.6 & 29.7 & 39.4 & 54.7 \\
\hline$P i 4^{a}(t)^{T T P}$ & 4.7 & 3.8 & 9.5 & 0.8 & $41.9 * *$ & $33.9 * *$ & $41.7 * *$ & 44.4 & 12.4 & 43.6 & 36 & 35.5 & 3.7 & 23.5 & 31.3 & 43.4 \\
\hline$P i 4^{b}(t)$ & 4.0 & 2.7 & $8.2 * *$ & 0.6 & $25.6^{*}$ & $19.3 * *$ & $24.7 *$ & $23.3 * *$ & 28 & 27.5 & 22.7 & 22.4 & 2.3 & 14.8 & 19.7 & 27.4 \\
\hline Pia & 5.9 & 4.2 & 11.4 & 1.1 & 55.4 & 36 & 56 & 44.2 & 28 & 98.3 & 79.6 & 78.6 & 8.2 & 52.1 & 69.2 & 96 \\
\hline$P i-k m$ & 5.1 & 3.6 & 10.1 & 0.8 & 44.2 & 28.4 & 44.6 & 33.3 & 25.2 & 80.2 & 81 & 64.8 & 6.7 & 42.9 & 57 & 79.1 \\
\hline$P i-t a$ & 4.9 & 3.8 & 9.9 & 0.8 & 44 & 28 & 44.2 & 34 & 24.5 & 79.3 & 75.5 & 80 & 6.6 & 42.4 & 56.4 & 78.2 \\
\hline$P i-t a^{2}$ & 0.5 & 1.1 & 0.8 & 0 & 5.3 & 3.2 & 5.7 & 4.4 & 3.4 & 8.2 & 7.6 & 7.8 & 8.3 & 4.4 & 5.8 & 8.1 \\
\hline$P i-b$ & 4.2 & 2.8 & 7.8 & 0.6 & 24.5 & 19 & 32 & 25 & 18.6 & 52.5 & 50.3 & 50 & 6.3 & 53 & 37.3 & 51.8 \\
\hline$P i-k p$ & 4.9 & 3.8 & 8.9 & 0.9 & 40.4 & 25.2 & 39.8 & 30.5 & 23 & 69.4 & 65.6 & 65 & 7.2 & 50.3 & 70.4 & 68.8 \\
\hline$P i-k$ & 5.9 & 4.2 & 11.4 & 1.1 & 54.6 & 35.3 & 54.8 & 43.6 & 27 & 96 & 80 & 78.9 & 8.1 & 53 & 70 & 97.7 \\
\hline
\end{tabular}

$\mathrm{z} *$ significantly different at $P \leq 0.05$ by chi-square test with $1 \mathrm{df}$. $* *=$ significantly different at $P \leq 0.01$ by chi-square test with $1 \mathrm{df}$. 
sity there $(31,39)$. Disequilibrium among avirulence loci suggests that sexual recombination does not explain the pathotypic diversity reported here. Research on association of virulence in barley powdery mildew (2) suggests that, for populations in which sexual recombination contributes to pathotypic diversity, the distribution of virulence genes follows a binomial distribution. However, for wheat stem rust, associations among inferred avirulence genes were stronger and more frequent in asexual than in sexual populations (1), and there were more pathotypes, which were more evenly distributed in sexual versus asexual populations $(15,36)$. While recombination can produce large numbers of pathotypes, high mutation rates at avirulence loci can as well. Thus, the role of recombination in generating pathotypic diversity in Thailand is not clear and deserves further scrutiny.

Specific incompatibility among all isolates of well-sampled lineages and one resistance gene as described for other populations (49) was detected in this population. As in the Philippine populations, this specificity was limited to $P i$ and $P i \quad z-5$. While all isolates tested in many lineages were incompatible with a number of other NILs, these lineages were represented by relatively few isolates. It is possible that, with larger sample sizes, compatible isolates would be encountered. Among well-represented pathotypes, I and L (with only 4 and 3 avirulences, respectively) were found in many lineages, suggesting that there is little major fitness effect among virulence combinations, other than perhaps $P i$ 1, $P i z-5$, and $P i t a^{2}$, regardless of their genetic background.

No combination of resistance genes will confer complete immunity to all of the lineages detected in the Thailand populations. If, however, the very low frequencies of compatibility with $\mathrm{Pi} 1$ and $\mathrm{Pi} z-5$ do result from significant fitness penalties caused by dysfunction of the corresponding avirulence genes, then combinations of these resistance genes could confer broad and durable resistance to $P$. grisea in Thailand. Composite pathotypes (49) within lineages developed by assigning an incompatible reaction at $\leq 5 \%$ compatibility suggest that combining $P i \quad z-5$ and $P i t a^{2}$ would confer resistance against all lineages in Northeast and Central Thailand (Table 6). However, no resistance combination would be effective against lineage 7 in North Thailand. Seed transmission of $P$. grisea (28) and the wide distribution of some lineages call into question the effectiveness of undertaking a lineage exclusion based on breeding strategy for the different regions.

The observed and inferred virulence complexity suggest some guidelines for the Thai rice blast resistance breeding program. Major gene complexity should be complemented by genes for quantitative resistance against $P$. grisea that have been shown to reduce the rates of epidemics in different environments $(46,47)$. This is illustrated by the complete resistance of both IR36 and IR50 across Thailand. These cultivars apparently carry the same complement of major resistance genes $(17,50)$ and, based solely on their performance in Thailand, would appear equally useful in a breeding program and equally durable. However, in many tropical environments, IR50 is highly susceptible while IR36 shows significantly less disease development under identical circumstances. Segregating materials over several generations in pathotypically diverse environments conducive to blast epidemics have been shown to yield high levels of durable resistance that apparently combine major and minor resistance $(10,11)$. Since there are differences in the virulence spectrum across seasons and sites in the country, late segregating lines should be tested in as many different locations and years as practically feasible.

The reason for durability of complex resistance has sparked debate among plant pathologists and breeders $(21,32,33,34,45)$. One explanation rests upon the presumed low probability of mutations occurring in sufficient frequency to allow the development of pathogen lineages combining the necessary set of virulence alleles. Accumulation of some virulence combinations would be particularly difficult for exclusively asexually reproducing pathogens that cannot recombine mutations originating in different lineages. An alternative, although not opposing, view is that loss of function of some avirulence genes imposes a fitness penalty on the pathogen and that some combinations of genes are effectively lethal. In this study of Thai $P$. grisea populations, we have observed many virulence alleles in single isolates that presumably reflect the results of many independent mutations. The rarity of $\mathrm{Pi} 1, \mathrm{Piz}$ 5, and $P i t a^{2}$ mutations to virulence suggests that a characteristic of the locus or of the avirulence gene product is responsible. Although the data presented here tend to support the hypothesis that accumulated virulence can impose a fitness penalty, the effect does not appear to be great. Thus the degree, if any, of fitness penalty must be quantified for each gene. The availability of sexually fertile Thai $P$. grisea field isolates offers the promise of creating strains differing only in specific virulence alleles or allele combinations needed for such studies.

\section{ACKNOWLEDGMENTS}

The authors gratefully acknowledge the assistance of Thawatchai Phromraksa and Payorm Srichumpa, Ubon Rice Research Center, in the pathotype inoculations and financial support from the Rockefeller Rice Biotechnology Program. The senior author is especially grateful to $\mathrm{M}$. Levy for his assistance in the determination of lineages, which will appear in another work.

\section{LITERATURE CITED}

1. Alexander, H. M., Roelfs, A. P., and Groth, J. V. 1984. Pathogenicity associations in Puc- cinia graminis f. sp. tritici. Phytopathology 74:1161-1166.

2. Andrivon, D., and de Vallavieille-Pope, C. 1993. Racial diversity and complexity in regional populations of Erysiphe graminis f. sp. hordei in France over a 5-year period. Plant Pathol. 42:443-464.

3. Andrivon, D., and de Vallavieille-Pope, C. 1995. Race diversity and complexity in selected populations of fungal biotrophic pathogens of cereals. Phytopathology 85:897905.

4. Bonman, J. M., Vergel de Dios, T. I., Bandong, J. M., and Lee, E. J. 1987. Pathogenic variability of monoconidial isolates of Pyricularia oryzae in Korea and in the Philippines. Plant Dis. 71:127-130.

5. Brown, A. H. D., Feldman, M. W., and Nevo, E. 1980. Multilocus structure of natural populations of Hordeum spontaneum. Genetics 96:523-536.

6. Chang, T. T. 1976. Rice: Oryza sativa and Oryza glaberrima (Gramineae-Oryzeae). Pages 98-104 in: Evolution of Crop Plants. N. W. Simmonds, ed. Longman Inc., New York.

7. Chen, D. H., Zeigler, R. S., Ahn, S. W., and Nelson, R. J. 1996. Phenotypic characterization of the rice blast resistance gene $P i-2(t)$. Plant Dis. 80:52-56.

8. Chen, D. H., Zeigler, R. S., Leung, H., and Nelson, R. J. 1995. Population structure of Pyricularia grisea at two screening sites in the Philippines. Phytopathology 85:10111020.

9. Colwell, R. K., and Coddington, J. A. 1995 Estimating terrestrial biodiversity through extrapolation. Pages 101-118 in: Biodiversity Measurement and Estimation. D. L. Hawksworth, ed. The Royal Society and Chapman and Hall, London.

10. Correa Victoria, F. J., and Zeigler, R. S. 1993 Pathogenic variability in Pyricularia grisea at a rice blast "hot spot" breeding site in eastern Colombia. Plant Dis. 77:1029-1035.

11. Correa Victoria, F. J., and Zeigler, R. S. 1995. Stability of partial and complete resistance in rice to Pyricularia grisea under rainfed upland conditions in eastern Colombia. Phytopathology 85:977-982.

12. Goodwin, S. B., Saghai-Maroof, M. A., and Webster, R. K. 1993. Isozyme variation within and among populations of Rhynchosporium secalis in Europe. Annu. Rev. Phytopathol. 32:558-599.

13. Gotelli, N. J., and Graves, G. R. 1996. Null Models in Ecology. Smithsonian Institution Press, Washington, DC.

14. Groth, J. V., and Roelfs, A. P. 1982. Effect of sexual and asexual reproduction on race abundance in cereal rust fungus populations. Phytopathology 72:1503-1507.

15. Groth, J. V., and Roelfs, A. P. 1987. The concept and measurement of phenotypic diversity in Puccinia graminis on wheat. Phytopathology 77:1395-1399.

16. Hamer, J., Farrall, E. L., Orbach, M. J., Valent, B., and Chumley, F. G. 1989. Host species specific conservation of a family of repeated DNA sequences in the genome of a fungal plant pathogen. Proc. Natl. Acad. Sci. USA. 86:9981-9985.

17. International Rice Research Institute. 1998. Program Report for 1997. International Rice Research Institute, P.O. Box 933, Manila, The Philippines.

18. International Rice Testing Program. 1988. Standard Evaluation System for Rice, 3rd ed. International Rice Research Institute, P.O. Box 933, Manila, The Philippines.

19. Inukai, T., Nelson, R. J., Zeigler, R. S., Sarkarung, S., Mackill, D. J., Bonman, J. M., Takamure, I., and Kinoshita, T. 1994. Allelism of blast resistance genes in near- 
isogenic lines of rice. Phytopathology 84:1278-1283.

20. James, F. C., and Rathbun, S. 1981. Rarefaction, relative abundance, and diversity of avian communities. The Auk 98:785-800.

21. Kolmer, J. A., Dyck, P. L., and Roelfs, A. P. 1991. An appraisal of stem and leaf rust resistance in North American hard red spring wheats and the probability of multiple mutations to virulence in populations of cereal rust fungi. Phytopathology 81:237-239.

22. Kumar, J., Nelson, R. J., and Zeigler, R. S. 1999. Population structure and dynamics of Magnaporthe grisea in the Indian Himalayas. Genetics 152:971-984.

23. Levy, M., Correa-Victoria, F. J., Zeigler, R. S., $\mathrm{Xu}, \mathrm{S}$., and Hamer, J. E. 1993. Genetic diversity of the rice blast fungus in a disease screening nursery in Colombia. Phytopathology 83:1427-1433.

24. Levy, M., Romao, J., Marchetti, M. A., and Hamer, J. E. 1991. DNA fingerprinting with a dispersed repeated sequence resolves pathotypic diversity in the rice blast fungus. Plant Cell 3:95-102.

25. Ling, Z. Z., Mew, T. V., Wang, J., Lei, C., and Huang, N. 1995. Development of nearisogenic lines as international differentials of the blast pathogen. Int. Rice Res. Notes 20(1): 13

26. Liu, Y. C., and Milgroom, M. G. 1996. Correlation between hypovirus transmission and the number of vegetative incompatibility (vic) genes different among isolates from a natural population of Cryphonectria parasitica. Phytopathology 86:79-86.

27. Mackill, D. J., and Bonman, J. M. 1992. Inheritance of blast resistance in near-isogenic lines of rice. Phytopathology 82:746-749.

28. Manandhar, H. K., Lyngs Jørgensen, H. J., Smedegaard-Petersen, V., and Mathur, S. B. 1998. Seedborne infection of rice by Pyricularia oryzae and its transmission to seedlings. Plant Dis. 82:1093-1099.

29. Maynard Smith, J., Smith, N. H., O'Rourke, M., and Pratt, B. G. 1993. How clonal are bacteria? Proc. Natl. Acad. Sci. USA. 90:4384-4388.

30. Mekwatanakarn, P. 1999. Characterization of Pyricuralia grisea (Magnaporthe grisea) populations in Thailand using molecular marker, Mating type and pathotype. Ph.D. thesis. Kasetsart University, Thailand

31. Mekwatanakarn, P., Kositratana, W., and Zeigler, R. S. 1999. Sexual fertile Magnaporthe grisea rice pathogens in Thailand. Plant Dis. 83:939-943.

32. Mundt, C. C. 1990. Probability of mutation virulence and durability of resistance gene pyramids. Phytopathology 80:221-223.

33. Mundt, C. C. 1991. Probability of mutation virulence and durability of resistance gene pyramids: Further comment. Phytopathology 81:240-242.

34. Parlevliet, J. E. 1981. Stabilizing selection in crop pathosystems: An empty concept or a reality? Euphytica 30:259-269.

35. Pimentel, R. A. 1993 Biostat III. An Ecological Statistics Toolbox (Version 2.0). Sigma Soft, San Luis Obispo, CA

36. Roelfs, A. P., and Groth, J. V. 1980. A comparison of virulence phenotypes in wheat stem rust populations reproducing sexually and asexually. Phytopathology 70:855-862.

37. Rossman, A. Y., Howard, R. J., and Valent, B. 1990. Pyricularia grisea, The correct name for the rice blast disease fungus. Mycologia 82:509-512.

38. Roumen, E., Levy, M., and Notteghem, J. L. 1997. Characterization of the European pathogen population of Magnaporthe grisea by DNA fingerprinting and pathotype analysis. Eur. J. Plant Pathol. 103:363-371.

39. Roumen, E., Luangdsa-ard, J., Sirithunyal, P., Na-Lampang, A., Saranum, S., Pimpisitthavborn, S., Boonchitsirikul, C., and Pan, Q. 1998. Population genetic studies on the rice blast pathogen, Magnaporthe grisea, in Thailand. Page 42 in: Program Abstracts, International Rice Blast Conference, 2nd. CIRAD, Montpellier, France.

40. Sheldon, A. L. 1969. Equitability indices: Dependence on the species count. Ecology 50:466-467.

41. Shull, V., and Hamer, J. 1994. Genomic structure and variability in Pyricularia grisea. Pages 65-86 in: Rice Blast Disease. R. S. Zeigler, S. Leong, and P. S. Teng, eds. Commonwealth Agricultural Bureaux International, Wallingford, Eng.

42. Silue, D., Tharreau, D., and Notteghem, J. L. 1992. Evidence of a gene-for-gene relationship in the Oryza sativa-Magnaporthe grisea pathosystem. Phytopathology 82:577-580.
43. Simberloff, D. 1978. Use of rarefaction and related methods in ecology. Pages 150-165 in: Biological Data in Water Pollution Assessment: Quantitative and Statistical Analyses. K. L. Dickson, J. Cairns, Jr., and R. J. Livingston, eds. American Society for Testing and Materials, Philadelphia, PA.

44. Stephens, M. A. 1974. EDF statistics for goodness-of-fit and some comparisons. J. Am. Stat. Assoc. 69:730-737.

45. Vanderplank, J. E. 1968. Disease resistance in Plants. Academic Press, London.

46. Wang, G. L., Mackill, D. J., Bonman, M., McCouch, S. R., Champoux, M., and Nelson, R. J. 1993. RFLP mapping of genes conferring complete and partial resistance to blast in a durably resistant rice cultivar. Genetics 136:1421-1434

47. Wang, Z., Mackill, D. J., and Bonman, J. M. 1989. Inheritance of partial resistance to blast in indica rice cultivars. Crop Sci. 29:848-853.

48. Xia, J. Q., Correll, J. C., Lee, F. N., Marchetti, M. A., and Rhoads, D. D. 1993. DNA fingerprinting to examine microgeographic variation in the Magnaporthe grisea (Pyricularia grisea) population in two rice fields in Arkansas. Phytopathology 83:1029-1035.

49. Zeigler, R. S., Cuoc, L. X., Scott, R. P., Bernardo, M. A., Chen, D. H., Valent, B., and Nelson, R. J. 1995. The relationship between lineage and virulence in Pyricularia grisea in the Philippines. Phytopathology 85:443-451.

50. Zeigler, R. S., Guico, E., Scott, R., and Nelson, R. J. 1996. Relationship between partia resistance and susceptibility of rice cultivars lineages of Pyricularia grisea. Oryza 33:273-281.

51. Zeigler, R. S., Scott, R. P., Leung, H., Bordeos, A. A., Kumar, J., and Nelson, R. J. 1997. Evidence of parasexual exchange of DNA in the rice blast fungus challenges its exclusive clonality. Phytopathology 87:284294.

52. Zeigler, R. S., Thome, J., Nelson, R. J., Levy, M., and Correa-Victoria, F. 1994. Linking blast population analysis to resistance breeding: A proposed strategy for durable resistance. Pages 267-292 in: Rice Blast Disease. R. S. Zeigler, S. Leong, and P. S. Teng, eds. Commonwealth Agricultural Bureaux International, Wallingford, Eng. 